Freshwater Fungi as a Source of Chemical Diversity: A Review

By: Tamam El-Elimat, Huzefa A. Raja, Mario Figueroa, Ahmed H. Al Sharie, Rick L. Bunch, and Nicholas H. Oberlies

Tamam El-Elimat, Huzefa A. Raja, Mario Figueroa, Ahmed H. Al Sharie, Rick L. Bunch, and Nicholas H. Oberlies. Freshwater Fungi as a Source of Chemical Diversity: A Review. Journal of Natural Products. 2021, 84, 3, 898-916. https://doi.org/10.1021/acs.jnatprod.0c01340

***(C) 2021 The Authors.***

c) (i) $\ominus$

EY NO ND This work is licensed under a Creative Commons Attribution-

NonCommercial-NoDerivatives 4.0 International License.

\title{
Abstract:
}

As their name indicates, freshwater fungi occur on submerged substrates in fresh water habitats. This review brings together the chemical diversity and biological activity of 199 of the 280 known freshwater fungal metabolites published from 1992 to 2020, representing at least seven structural classes, including polyketides, phenylpropanoids, terpenoids, meroterpenoids, alkaloids, polypeptides, and monosaccharides. In addition to describing what they are, where they are found, and what they do, we also discuss strategies for the collection, isolation, and identification of fungi from freshwater habitats, with the goal of enhancing chemists' knowledge of several mycological principles. We anticipate that this review will provide a springboard for future natural products studies from this fascinating but underexplored group of Ascomycota.



Keywords: fungi | natural products | pharmaceuticals | fresh water | metabolism Article:

$* * *$ Note: Full text of article below 


\section{Freshwater Fungi as a Source of Chemical Diversity: A Review}

Tamam El-Elimat,* Huzefa A. Raja, Mario Figueroa, Ahmed H. Al Sharie, Rick L. Bunch, and Nicholas H. Oberlies*

Cite This: J. Nat. Prod. 2021, 84, 898-916

Read Online

ABSTRACT: As their name indicates, freshwater fungi occur on submerged substrates in fresh water habitats. This review brings together the chemical diversity and biological activity of 199 of the 280 known freshwater fungal metabolites published from 1992 to 2020, representing at least seven structural classes, including polyketides, phenylpropanoids, terpenoids, meroterpenoids, alkaloids, polypeptides, and monosaccharides. In addition to describing what they are, where they are found, and what they do, we also discuss strategies for the collection, isolation, and identification of fungi from freshwater habitats, with the goal of enhancing chemists' knowledge of several mycological principles. We anticipate that this review will provide a springboard for future natural products studies from this fascinating but underexplored group of Ascomycota.

\section{INTRODUCTION}

Fungi are prolific producers of secondary metabolites and have been studied intensively for years in the quest for new secondary metabolites. ${ }^{1}$ They are ecologically, morphologically, physiologically, phylogenetically, and chemically diverse organisms that are seen in nearly all environments, including terrestrial, freshwater, and marine habitats. ${ }^{2}$ In the present review, we focus on fungal secondary metabolites isolated from freshwater fungi in the phylum Ascomycota exclusive of the yeasts. These microscopic freshwater Ascomycota encompass both the sexual state (meiosporic or teleomorphic) and the asexual states (also referred to as mitosporic or hyphomycetes or anamorphic). ${ }^{3-5}$ While members of the Basidiomycota also occur in fresh water, only about 40 species have been described exclusive of the yeasts. ${ }^{6}$ Members of this taxonomic group will not be discussed further, although freshwater basidiomycetes represent a ripe area for future study. Definitions of several other non-ascomycete freshwater fungi have been outlined recently ${ }^{7}$ and will not be covered in this review.

There are many goals with this review. An overarching aim is to bring clarity to the definition of freshwater fungi with respect to the literature on natural products chemistry of new molecules from these organisms, analogous to what has been accomplished recently for marine fungi. ${ }^{8,9}$ There are also a series of pragmatic goals, such as explaining how to collect them; how to isolate them in culture so as to study their chemistry; how to taxonomically identify them using both morphological and molecular methods; and what is known about the secondary metabolites from freshwater fungi. Finally, we provide a synthesis of the literature from the numerous

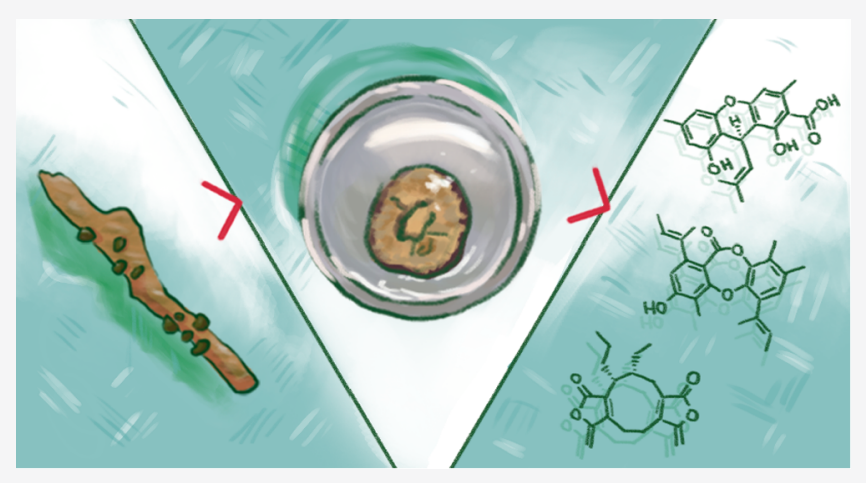

natural products studies on freshwater fungi. We conclude with ideas of how scientists can bridge the knowledge gap of natural products chemistry from this poorly studied ecological niche. For clarity, a glossary of mycology and ecology terms that may be unfamiliar to chemists has been provided (Table 1).

\section{PART I: BIODIVERSITY OF FRESHWATER FUNGI}

Defining the Diverse Types of Ascomycota in Fresh Water. Fungi occurring in fresh water comprise a phylogenetically diverse group of Ascomycota, and these can be defined as an ecological assembly rather than a taxonomic group, indicating that freshwater fungi occur in different lineages. The groups recognized in fresh water as decomposers of coarse particulate organic matter ${ }^{10}$ are both sexual (teleomorphic) ascomycetes ${ }^{3,4,11}$ and asexual (anamorphic) ascomycetes. The asexual ascomycetes constitute three types based on their ecological adaptations to freshwater habitats: aquatic hyphomycetes (also known as Ingoldian fungi), ${ }^{12,13}$ aeroaquatic hyphomycetes, ${ }^{11,14}$ and the submerged-aquatic hyphomycetes (or miscellaneous freshwater mitosporic fungi). ${ }^{3,11,15}$ Collectively, all sexual and asexual fungi will be referred to as "freshwater fungi", since from the perspective of secondary

Special Issue: Special Issue in Honor of A. Douglas Kinghorn

Received: December 14, 2020

Published: March 4, 2021






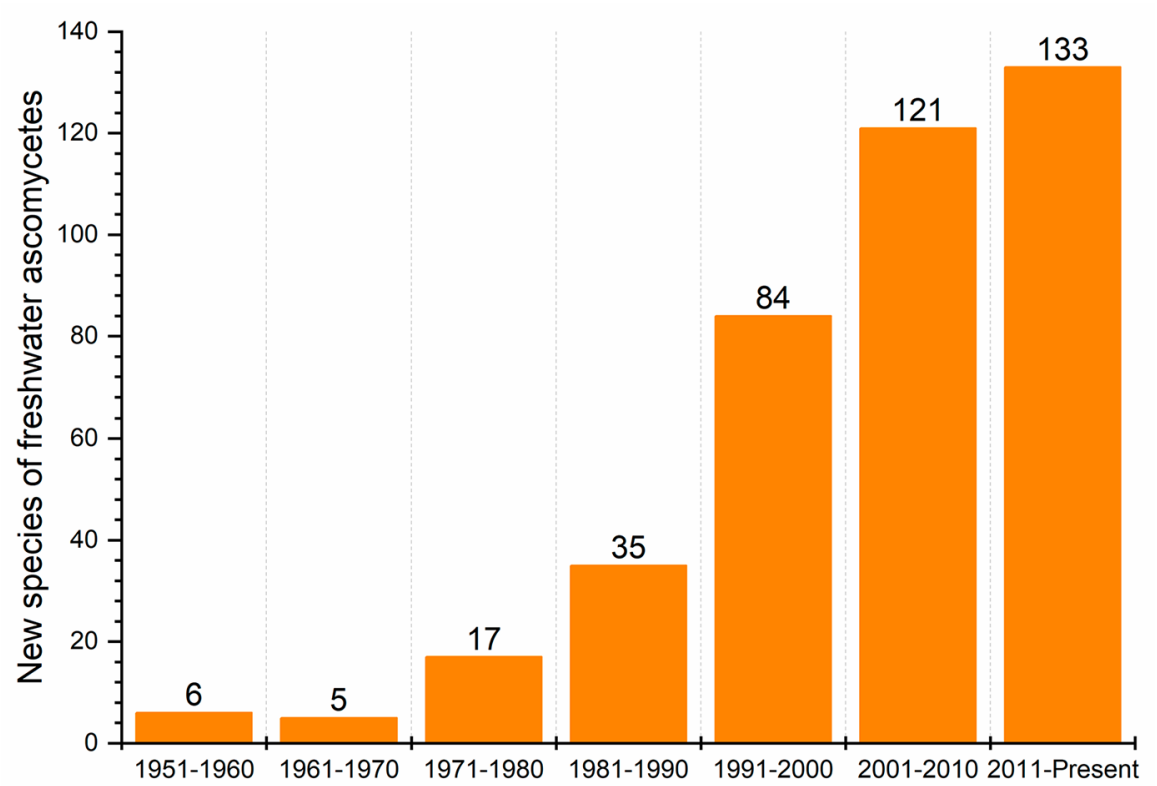

Figure 1. Number of new freshwater ascomycetes described from freshwater habitats. Professor C. T. Ingold, the first to recognize the occurrence of a distinctive freshwater Ascomycota, published a series of papers about fungi on submerged substrates in the Lake District, England, between 1951 and $1955 .{ }^{21-24}$ Note the increase since the reviews by Shearer on the freshwater ascomycetes in 1993 and 2001.4

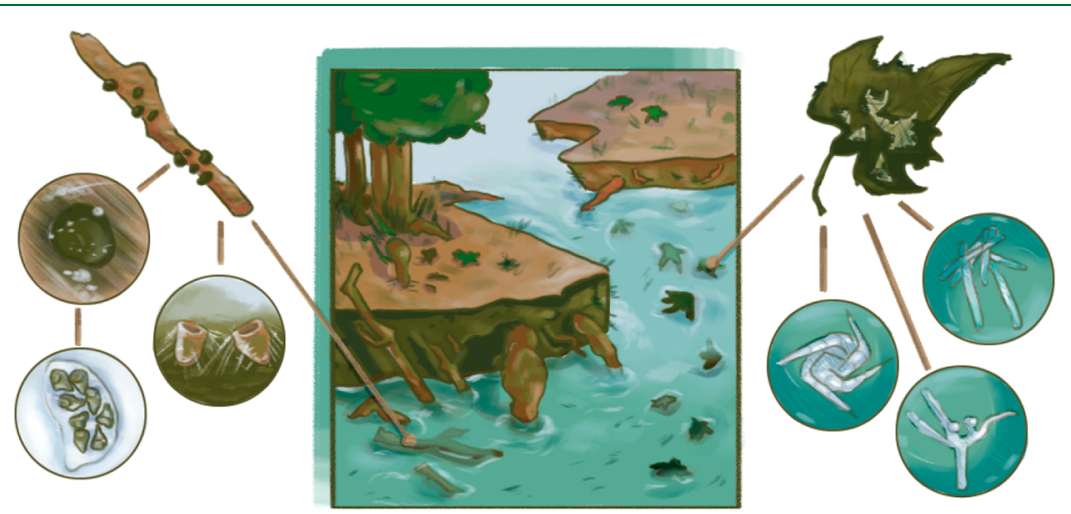

Figure 2. Infographic displaying the types of freshwater fungi. A freshwater stream is meandering through a riparian zone. Submerged dead wood and herbaceous materials, such as leaf litter, fall from these trees into the stream and are decomposed by freshwater fungi. Upon incubating submerged wood in plastic boxes with moistened paper towels, fruiting bodies of freshwater ascomycetes (sexual states; left) form on the wood. When decomposed leaf litter is cut into circles and submerged in distilled water, after a few days, Ingoldian hyphomycetes (asexual states; right) appear floating in the water. The sexual (teleomorphic) forms are more prevalent on submerged wood, while the asexual (anamorphic) forms usually occur on submerged leaf litter.

metabolites, both states produce interesting chemical diversity. However, throughout this review, we will refer to the sexual (teleomorphic) stages as "freshwater ascomycetes" and the asexual (anamorphic) stages as "hyphomycetes". In addition, we use ecological terms, such as aquatic hyphomycetes, aeroaquatic hyphomycetes, and submerged aquatic hyphomycetes, while referring to specific ecological groups of asexual states.

About 738 species of ascomycetes have been reported from freshwater habitats ${ }^{3}$ (http://fungi.life.illinois.edu). While this number has increased over the last 30 years (Figure 1), particularly since the review by Shearer ${ }^{4}$ in 1993, it still represents less than $1 \%$ of the over 135000 fungi that have been described ${ }^{16}$ (and a tiny fraction of the estimated 2 to 5 million species of fungi in the world). ${ }^{17,18}$ Freshwater ascomycetes occur on submerged or partially submerged substrates in lotic (i.e., moving water found in brooks, streams, and rivers) and lentic (i.e., static water found in lakes, swamps, and bogs) aquatic habitats (Figure 2). ${ }^{4,5}$ The substrates comprise either the dead and decaying stems of aquatic herbaceous macrophytes that grow in fresh water or the decayed wood and decomposing leaves that fall into fresh water from adjacent riparian vegetation (Figure 2). ${ }^{4,19}$ The small microscopic fruiting bodies (termed ascomata) are often completely or partially seated in the substrates, thus allowing them to stay attached, even in rapidly moving water. The ascospores can be either passively or actively dispersed from the ascomatal cavity. Sheaths and appendages on ascospores facilitate floatation, enabling longer dispersal and efficient attachment to new surfaces to further propagate the cycle of life (Figure 3). ${ }^{4,15,20}$

Different Ecological Groups of Asexual Ascomycetes. The first species of aquatic hyphomycetes was described in 1880 . However, it was not until the British mycologist Sir Cecil 

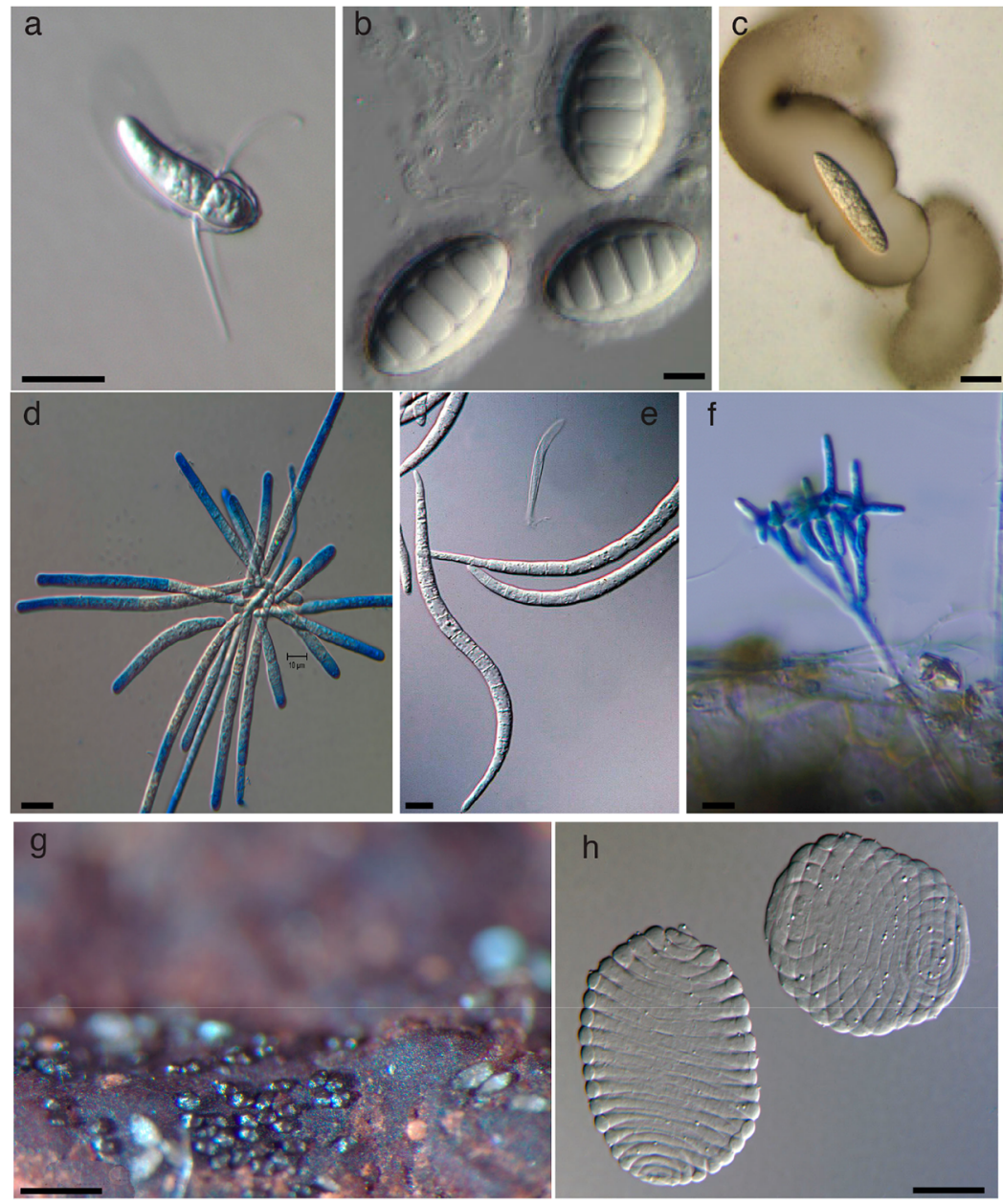

Figure 3. Variety of ascospores and conidia of freshwater ascomycetes and hyphomycetes. Panels a-c, freshwater ascomycetes: (a) Minutisphaera fimbriatispora (picture credit, C. A. Shearer), (b) Luttrellia halonata (picture credit, A. Ferrer), and (c) Lindgomyces ingoldianus. Panels d-f, conidia of aquatic (Ingoldian) hyphomycetes: (d) Dendrospora erecta, (e) Anguillospora crassa, and (f) Lemonniera sp. Panels g and h, conidia of aeroaquatic hyphomycetes: (g) Cancellidium applanatum (picture credit, S. E. Zelski), and (h) Helicodendron sp. (picture credit, C. A. Shearer). Scale bars: a, c, $\mathrm{f}, \mathrm{h}=20 \mu \mathrm{m}, \mathrm{b}, \mathrm{d}, \mathrm{e}=10 \mu \mathrm{m}, \mathrm{g}=200 \mu \mathrm{m}$.
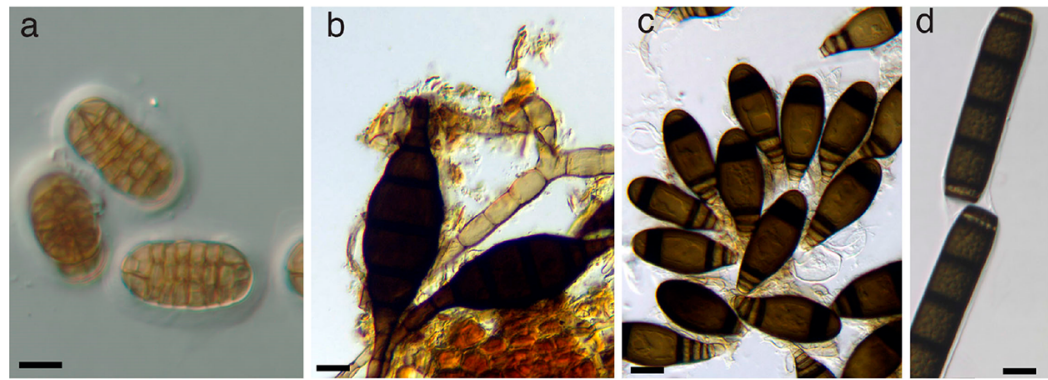

Figure 4. Conidia of submerged-aquatic hyphomycetes or miscellaneous freshwater mitosporic fungi: (a) Coleodictyospora sp., (b) Xylomyces sp., (c) Bactrodesmium abruptum, and (d) Sporoschisma saccardoi. Scale bars: a-d $=10 \mu \mathrm{m}$ (images taken from the Freshwater Ascomycetes Database: http://fungi.life.illinois.edu, maintained by C. A. Shearer and H. A. Raja).

Terence Ingold recognized numerous species of aquatic hyphomycetes on decomposing alder and willow leaves, and thus these fungi have been referred to as Ingoldian hyphomycetes. ${ }^{25-27}$ These tetradiate, branched, or sigmoidalshaped fungi (Figures 2 and 3) complete their asexual life cycle, including vegetative growth, spore production, spore liberation, and dissemination, on submerged substrates in wellaerated waters, such as streams and brooks. The aquatic hyphomycetes commonly occur on large particulate organic material, such as decomposing leaf litter ${ }^{26}$ and submerged woody debris. $^{28}$

The aeroaquatic hyphomycetes are most commonly found on submerged wood and herbaceous material in lentic bodies of water, such as ponds, ditches, or slow running streams, and are capable of vegetative (i.e., hyphal) growth on submerged substrates under semi-anaerobic conditions. ${ }^{1,29-35}$ This ecological group is able to grow in a vegetative phase on substrates that are completely submerged and form conidia 


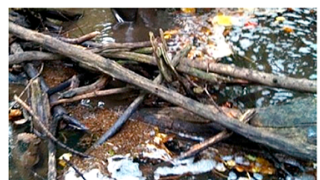

a) submerged wood

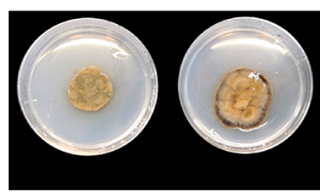

f) pure cultures



b) plastic bags with paper towels

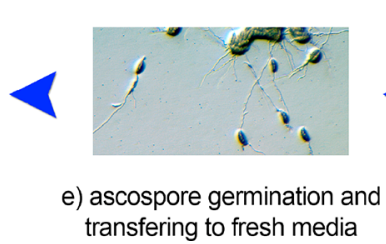

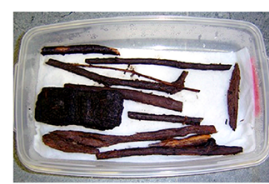

c) wash and incubate



d) fruiting bodies

Figure 5. Outline of the stages of collection, transport, incubation, and isolation of freshwater ascomycetes: (a) Submerged wood or herbaceous material is collected from freshwater habitats; (b) the soft decorticated material is put in plastic bags with a lining of paper towels to absorb excess water. Substrates should be moist but not overly wet; (c) in the lab, the substrates are rinsed with distilled water and placed in a covered plastic box with moist paper towels; (d) the substrates are examined monthly for 3-6 months for sexual (asci and ascospores) or asexual (conidia) structures; (e) with a pair of sterile needles, the spores (whether sexual or asexual) are gently spread on the surface of the water agar with antibiotics; (f) after 24-48 h, depending on rate of germination, the spores are aseptically transferred to nutrient agar, such as potato dextrose; antibiotics are included in the media to prevent growth of bacteria, which can be prevalent in fresh water.

(asexual spores) with special characteristics when the substrate is exposed to the air-water interphase (Figure 3). ${ }^{14}$

The third ecological group of asexual ascomycetes is referred to as the submerged-aquatic hyphomycetes ${ }^{3,11}$ and coelomycetes. $^{36,37}$ These fungi do not possess specialized spore structures (Figure 4), such as those observed with the Ingoldian hyphomycetes or the aeroaquatic hyphomycetes. Rather, they are an artificial assemblage of asexual (anamorphic) fungi that are phylogenetically and morphologically diverse within the Ascomycota. ${ }^{11,38-40}$

Collection and Isolation of Freshwater Fungi with Special Reference to Those Inhabiting Wood. A series of methods for the collection, isolation, and preservation of cultures of freshwater ascomycetes have been detailed by Shearer et al., ${ }^{41}$ and additional methods can be found in a book by Tsui and Hyde. ${ }^{40}$ Herein, we outline some important considerations for collecting and isolating freshwater ascomycetes (Figure 5). These fungi are microscopic (i.e., about 0.5 $\mathrm{mm}$ width and height of fruiting bodies), ${ }^{3}$ and thus, the best way to collect them is to collect their substrates, such as submerged dead and decaying wood and herbaceous materials that have been in fresh water for a relatively long time period (i.e., weeks to about six months or longer). In the field a common solution is to collect materials that are starting to decompose and can easily be broken due to fungal soft rot. ${ }^{42,43}$ These materials should be collected in plastic bags lined with paper towels and transported to the laboratory for further study. The paper towels will absorb excess water, which will keep the substrates moist but not overly wet. Unfortunately, overly wet substrates encourage growth of bacteria and/or certain fast growing mold species, such as Aspergillus, Penicillium, and Trichoderma, which are not true freshwater fungi $^{44-46}$ (with the exceptions of Trichoderma matsushimae and T. aeroaquaticum ${ }^{47}$ ). Ideally, submerged substrates should be collected at random, and we advocate for the sampling of both lotic and lentic habitats, since the differences in substrates due to differences in vegetation, water flow vs stagnation, and oxygen levels likely impart variety in the suite of fungal species. ${ }^{48}$ By far, submerged wood has been the most examined substrate for isolation of freshwater ascomycetes, $4,5,15,48,49$ since it is found commonly, is easy to collect, and, perhaps most importantly, remains in the water for longer periods of time than leaves or grasses. ${ }^{10}$ Fungi decompose wood in terrestrial habitats too, but the mass loss due to fragmentation and leaching in streams is $\sim 9 \%$ faster in submerged environments. ${ }^{50}$ An alternative method involves the use of suitable baits (e.g., sterilized twigs or wood panels) anchored with bricks in the water of a particular study site for colonization of freshwater fungi. ${ }^{50-52}$ In general, these latter studies are usually performed by scientists interested in ecology or taxonomy and systematics rather than those seeking fungi for natural products discovery purposes, probably because few collaborations exist between freshwater fungal taxonomists and natural products chemists.

Once the samples are in the laboratory, they are gently rinsed with distilled water, but care should be taken to ensure the substrates are not scrubbed too vigorously, which would lead to loss of sediments and possibly the hyphae of freshwater fungi. ${ }^{41}$ The substrates are then incubated in plastic boxes with moist paper towels for 3-6 months in $12 \mathrm{~h}$ light/dark cycles; care should be taken to prevent contamination with mites. The samples are periodically examined for fruiting bodies of freshwater ascomycetes and conidiophores and conidia of the asexual fungi. Cultures can be obtained from either single ascospores or ascospores contained in single asci with sterile dissecting or sewing needles. The ascomata (from sexual reproduction) or conidia (from asexual reproduction) are removed from the substrates and spread on the surface of antibiotic water agar plates (AWA, agar $20 \mathrm{~g}$, streptomycin sulfate $250 \mathrm{mg} / \mathrm{L}$, penicillin $\mathrm{G} 250 \mathrm{mg} / \mathrm{L}$, distilled water $1 \mathrm{~L}$; antibiotics are added to the molten agar immediately after autoclaving). With a dissecting microscope illuminated with fluorescent light from below, the germinating ascospores or conidia are cut out from the AWA and transferred to plantbased media, such as corn meal agar (CMA) or potato dextrose agar (PDA). For long-term storage of cultures (i.e., 6-12 months), short strips of autoclaved moistened balsa or birch wood can be added to slants of CMA or PDA media to provide a long lasting substratum. ${ }^{41}$ 
For detailed methods on collection and isolation of aquatic hyphomycetes, which commonly occur on autumn shed leaf litter, readers are encouraged to refer to methods outlined previously. ${ }^{41,53}$ Aquatic hyphomycetes are also found on submerged wood; however, wood pieces/twigs need to be placed in cylindrical tubes with sterile water and sterile air. ${ }^{28,54}$ Subsequently, the conidia can be isolated and cultured, or the conidial suspension can be membrane filtered, and the resulting conidia examined after staining in lactic acid with cotton blue. $^{41}$ For the most part, likely due to the complications associated with their collection and isolation from nature, the aquatic hyphomycetes have only rarely been part of natural products chemistry studies, ${ }^{55-57}$ presenting an obvious opportunity for future research.

Growing Freshwater Fungal Cultures for Natural Products Chemistry Studies. One might argue that since freshwater fungi grow in aquatic environments, liquid media would be most suitable for their growth for natural products chemistry studies. We have tried such strategies, but none of the liquid media we have examined, including Czapek Dox (CD), 2\% malt extract (ME), potato dextrose (PD), yeast extract soluble starch (YPSS), yeast extract soy peptone dextrose (YESD), and peptone yeast glucose, ${ }^{58}$ were useful for growing freshwater fungi for isolation of secondary metabolites. While these fungi would grow in liquid media, they did not produce a rich organic extract, and that, in turn, would serve to complicate the natural products chemistry studies. ${ }^{58}$ Thus, we have found that first growing the fungus in a liquid seed media, followed by inoculation on solid grain based media, such as rice or oatmeal, was the most optimal method of growing freshwater fungi for extraction and isolation of secondary metabolites. ${ }^{59-64}$ Briefly, once a pure culture is obtained, a small square of agar with the fungal hyphae is cut out aseptically from the leading edge of a 2-3-week-old culture and transferred to a sterile $50 \mathrm{~mL}$ Falcon tube with $10 \mathrm{~mL}$ of YESD liquid media for seed culture. These samples are then incubated at room temperature on an orbital shaker $(\sim 100$ $\mathrm{rpm}$ ) until mycelium is observed. Solid-state fermentation on grain-based substrates, such as rice or oatmeal, is prepared by adding $10 \mathrm{~g}$ of substrate into a $250 \mathrm{~mL}$ Erlenmeyer flask with 20 or $15 \mathrm{~mL}$ of DI water for rice and oatmeal, respectively, and then autoclaved at $121{ }^{\circ} \mathrm{C}$ for $30 \mathrm{~min}$. The seed cultures are then poured on top of the grain under sterile conditions, and these cultures are then fermented statically at room temperature for 14 to 21 days or until the grain is completely colonized by fungal growth. When striving to optimize fermentation conditions, it may also be prudent to observe the mycelia for differentiation (e.g., sporulation) and measure the $\mathrm{pH}$ of the cultures. While the above methods largely ensure good growth of the freshwater fungal cultures, we know there is room for new ideas. For example, we recently found that adding autoclaved balsa wood to both the seed cultures and the static cultures enhanced the growth of freshwater fungi, resulting in a larger profile of secondary metabolites. This area of experimentation is ripe for further innovations.

Identification of Freshwater Fungi. Early efforts to name and classify freshwater fungi focused on integrating taxa within the existing taxonomic/morphological framework for ascomycetes, ${ }^{65,66}$ and for this some useful resources are available. ${ }^{3,6,39,40,67,68}$ However, convergent or parallel evolutions in morphological characters that are subject to positive selection in aquatic habitats confound our understanding of true evolutionary relationships. ${ }^{69}$ There are many examples, but the most obvious are ascospores with gelatinous sheaths and/or appendages, which allow these fungi to "stick" to substrates. Pragmatically, morphological identification requires specialized training in freshwater mycology, and while those skills are somewhat rare, such morphological studies serve as a backbone from which newer, DNA-based approaches can be leveraged. Thus, due, at least in part, to the lack of experts in morphological taxonomy, molecular phylogenetic techniques and DNA barcoding approaches ${ }^{70}$ have emerged for identification and description of novel freshwater ascomycete taxa and connection of asexual taxa with the sexual ascomycete groups. $^{71}$

Recently, members of our research team have detailed strategies and guidelines for molecular identification of fungi, ${ }^{70}$ in general, and those approaches hold true for freshwater fungi. For this, it is useful to sequence the nuclear ribosomal (rRNA) genes, specifically the $18 \mathrm{~S}$ nuclear ribosomal small subunit rRNA gene (SSU), internal transcribed spacer region (ITS), and the $28 \mathrm{~S}$ nuclear ribosomal large subunit rRNA gene (LSU). Detailed methods for DNA extraction, PCR amplification, Sanger sequencing, and phylogenetic methods were outlined previously. ${ }^{70}$ The rRNA region has been historically used for fungal molecular systematics due to ease in amplification and sequencing as well as the high copy number subject to concerted evolution. ${ }^{72}$ For identification of genera and species, the LSU and ITS regions are recommended, while for the placement of newly isolated taxa, the SSU region is recommended. These ribosomal regions are useful, since there is a vast amount of sequence data available in NCBI GenBank from previous studies of freshwater fungi. ${ }^{68,73}$ These regions are utilized in both molecular phylogenetics and DNA barcoding of both freshwater ascomycetes ${ }^{6,73-76}$ and asexual freshwater fungi, including aquatic ${ }^{77-81}$ and aeroaquatic ${ }^{34,82}$ hyphomycetes. In addition to the ribosomal cassette of repetitive genes (18SITS1-5.8S-ITS2-28S) commonly used for fungal identification in the past 10 years, there has been a steady increase in the application of single-copy protein-coding data for molecular phylogenetic studies. ${ }^{83}$ Among protein-coding markers, the second largest (RPB2) subunit of RNA polymerase, translation elongation factor 1-alpha (tef1), and the mini-chromosome maintenance proteins (MCM7) are commonly used for inferring phylogenetic relationships among freshwater fungi. ${ }^{83-88}$ We suggest that researchers seriously consider using these protein-coding markers, as they can provide a more precise account of species resolution when data from ribosomal genes are not informative. ${ }^{70}$ Given the popularity of using molecular-based approaches, coupled with the relatively few experts in taxonomy and systematics of freshwater fungi, we anticipate that the use of these strategies will only grow over time.

Ecological Roles. Freshwater fungi, regardless if they reproduce sexually or asexually, are known to produce a suite of hydrolytic enzymes (i.e., amylases, cellulases, pectinases, xylanases, and peroxidases, among others $)^{89-91}$ on substrates such as submerged wood, leaf litter, and herbaceous debris. In addition to bacteria ${ }^{92,93}$ and invertebrates, ${ }^{94}$ these fungi are implicated as one of the key ecological groups capable of decomposing organic matter in freshwater habitats, $7,10,19$ mainly by forming soft-rot cavities. ${ }^{91,95,96}$ The sexual state of freshwater ascomycetes is most commonly found in decomposing submerged wood, ${ }^{52,90}$ since it remains in water for longer periods of time. Alternatively, the asexual states are 
most commonly implicated in decomposing deciduous leaf litter in streams, ${ }^{10,12,97,98}$ likely because the enzymes produced by these fungi have evolved to break down nonlignin substrates. In addition to ascomycetes, other fungal groups, such as Basidiomycota, Chytridiomycota, Mucoromycota, and Oomycota, are also reported to occur during leaf decomposition in freshwater streams. ${ }^{99}$

Not Everything Collected from "Fresh Water" Are "Freshwater Fungi". An overarching aim of this section is to bring some clarity to the definition of freshwater fungi. Shearer ${ }^{4}$ defined freshwater ascomycetes as microscopic saprobic fungi on submerged wood, leaves, and other herbaceous dead plant material that occur in both lentic and lotic habitats. They can also occur as parasites and endophytes of aquatic macrophytes. In her reviews, ${ }^{4,5}$ she argued that, just like with the aquatic and wetland plants, an accurate definition of what constitutes a freshwater ascomycete is problematic. This is because in many aquatic habitats there is a submersion gradient from land to water along a floodplain, and since the precise positions of such gradients may fluctuate seasonally and/or episodically with weather events, it is difficult to establish precise aquatic boundaries. ${ }^{4}$ Moreover, the degree of submergence of the substrates of freshwater ascomycetes can vary with fluctuations in water level. Many species reported from freshwater habitats are often reported from terrestrial habitats too, and it is challenging to determine their true environmental origin. ${ }^{4}$ Common examples, such as Penicillium spp. and Aspergillus spp., may be found in fresh water not because they are truly aquatic species, but rather they are ubiquitous and were washed into the stream or lake from terrestrial habitats. The definition of whether a species is freshwater or terrestrial based on its degree of submergence remains problematic. ${ }^{4,19}$

As increased sampling from freshwater habitats have been made over the last 40 years in both temperate and tropical habitats, our definition of freshwater fungi has evolved. ${ }^{3,19} \mathrm{~A}$ new ecological and phylogenetic definition of freshwater ascomycetes is emerging, largely due to recent taxonomic and ecological studies, some of which include systematically collecting and then describing both species and their function. In many cases, this has also included the application of molecular systematic techniques, thereby adding an orthogonal means of identification. We can now use the definition of Shearer ${ }^{4}$ together with the applications of molecular phylogenetic approaches to better define freshwater fungi as those occurring on submerged or partially submerged substrates in lotic and lentic habitats that belong to exclusive freshwater and/or aquatic phylogenetic lineages as freshwater indweller species. ${ }^{100}$ Some examples of true freshwater genera are Alascospora, Anguillospora, Aliquandostipite, Amniculicola, Aquadulciospora, Ascovaginospora, Ayria, Bullimyces, Cataractispora, Clavariopsis, Clohesyomyces, Helicoon, Hyalorostratum, Isthmosporella, Jahnula, Lindgomyces, Lepidopterella, Lucidascocarpa, Minutisphaera, Natipusilla, Tricladium, Wicklowia, and Xylomyces, to name a few. In contrast, those that occur on submerged substrates in fresh water, but are phylogenetically related to members of terrestrial lineages, are defined as freshwater immigrant species. ${ }^{100}$ Since biologists have a tendency to continually evolve their definitions, the terms periodic immigrants and versatile immigrants have recently been used for species of terrestrial origin reported in aquatic habitats. ${ }^{7}$ While these definitions will most likely continue to be refined, the basic idea is that true freshwater fungi have evolved adaptations that facilitate their survival in fresh water, and they are capable of maintaining their biomass at a site annually using the substrates and nutrients available in fresh water. ${ }^{4}$ While terrestrial species certainly wash into all types of fresh water, they are not considered as true members of the freshwater fungi until they are repeatedly isolated from fresh water, have morphological adaptations for survival in fresh water, and/or have affiliations with exclusive aquatic lineages via molecular phylogenetic approaches. ${ }^{6,101}$

Systematics of Freshwater Fungi. Currently about 738 species of freshwater ascomycetes are known from their sexual states belonging to approximately 170 genera. ${ }^{102}$ With respect to mitosporic fungi (i.e., asexual), greater than 900 species have been described. ${ }^{6,39,40,102}$ Freshwater sexual and asexual ascomycetes are polyphyletic within the phylum Ascomycota and are scattered throughout three main classes, namely, the Leotiomycetes (previously termed Discomycetes), Sordariomycetes (previously termed Pyrenomycetes), ${ }^{68}$ and Dothideomycetes (previously termed Loculoascomycetes). ${ }^{73,74}$ Currently, the reported freshwater ascomycetes are distributed in these orders: Helotiales, Pleurotheciales, Pleosporales, Sordariales, Savoryellales, Microascales, and Jahnulales. ${ }^{3}$ More recently, several new ordinal lineages of freshwater ascomycetes have been reported based on multigene phylogenetic analysis, including Natipusillales ${ }^{103}$ and Minutisphaerales ${ }^{87,104}$ in the Dothideomycetes ${ }^{74}$ and Annulatascales and Atractosporales $^{85}$ in the Sordariomycetes. ${ }^{105}$ There are numerous other genera of freshwater ascomycetes from both temperate and tropical latitudes, such as Bullimyces, Hydromelitis, Hanliniomyces, Hyalorostratum, Lucidascocarpa, Aquapoterium, Aquadiscula, and Frigidispora ${ }^{3}$ to name a few, that have been reported only once from freshwater habitats, and thus phylogenetic affiliation to any particular order or family is uncertain. As more freshwater fungi are studied in the future, our understanding of their systematics and taxonomy will continue to evolve.

Freshwater Fungal Genomes May Help Uncover Novel Secondary Metabolites. Approximately 1644 publicly available fungal genomes were utilized in the most recent phylogenomic study of the kingdom fungi. ${ }^{106}$ However, less than $1 \%$ (approximately 25 strains belonging to 10 genera) of these were from freshwater fungi (Table S1). This may be due to the paucity of taxonomists with expertise in this ecological group, and methodologies to extract high-quality DNA and RNA from freshwater fungi remain a challenge. Genomes of Tetracladium spp. have revealed an average of 24 biosynthetic gene clusters (BGCs) across this sexual freshwater fungal genus. ${ }^{107}$ In the genome of Lepidopterella palustris, a freshwater sexual species that colonizes submerged woody debris in cypress swamps, there were about 40 BGCs annotated. ${ }^{108}$ While the annotated BGCs suggest enzymes one would expect for the generation of secondary metabolites (polyketide synthases, nonribosomal peptide synthases, etc.), there are almost no secondary metabolites reported from cultures from either of these genera. Certainly, natural products chemistry studies on these genera of fungi represent a fertile area of research, as does the sequencing and annotation of many other species of freshwater fungi.

Genome studies have shown that fungi have a rich diversity of secondary metabolite pathways, ${ }^{109}$ but the genes and gene clusters in these biosynthetic pathways, and their secondary metabolite products, are largely unknown. ${ }^{110}$ This is because even recently isolated fungi may produce only minute amounts 
of secondary metabolites under laboratory conditions, while initially productive strains may become domesticated when repeatedly grown in the lab, leading to attenuation in the levels of products formed or loss of production altogether. ${ }^{11}$ Since gene clusters in genomes are evolutionary tools for chemical innovation, ${ }^{112}$ genome-enabled mycology ${ }^{113}$ and natural products research represent the leading edge to understand how genes and gene clusters (i.e., the genotype) produce novel secondary metabolites (i.e., the phenotype). The relationship between genotype and phenotype in fungal genomes is poorly understood. $^{114,115}$ This is especially true for "wild" freshwater fungi, harvested from the environment. Chemists and mycologists are encouraged to work in a collaborative manner, so we can acquire the genomes of freshwater fungi and then connect the genotype to phenotype. More genomes of freshwater fungi need to be sequenced, potentially using third-generation sequencing technologies such as Illumina Truseq, Oxford nanopore, or PacBio sequencing. ${ }^{116}$ These longread sequencing technologies may help acquire high-quality gene sequences to implement annotation of the secondary metabolite BGCs. Utilizing high-quality annotation of BGCs from sequenced genomes, coupled with secondary metabolite isolations and/or metabolomic studies, could help shed light on the uniqueness of secondary metabolite biosynthesis in freshwater fungi.

\section{PART II: CHEMICAL DIVERSITY OF FRESHWATER FUNGI}

Chemical Diversity and Biological Activities of Freshwater Fungal Secondary Metabolites. Over the past 30 years, many freshwater fungi have been subjected to chemical investigations resulting in the isolation of 283 secondary metabolites of wide chemical diversity and a broad range of biological activities. The fungal strains were collected from different locations in the world, particularly from the U.S. and China, and vast areas of the planet remain nearly uninvestigated (Figure 6). The present contribution summa-



Figure 6. Geographical distribution of the freshwater fungal strains sampled to study chemical diversity $(n=47)$. Large gaps remain in our knowledge regarding freshwater fungal chemical investigations. Notably, South America and Africa are two continents where there have been no chemical studies of freshwater fungi reported in the literature, which suggests that vast areas of the earth remain unsampled for freshwater fungal chemical diversity. rizes the most recent advances in the search for natural products from freshwater fungi since initial investigations reviewed by Gloer ${ }^{17,118}$ and Hernandez-Carlos and GamboaAngulo. ${ }^{119}$ The compounds are discussed based on the biosynthesis of their structural core.

Polyketides. For the past decade, our research group has systematically studied freshwater fungi isolated from geographically distinct locations in the state of North Carolina (USA). One of the first fungal species we studied was Paraphoma radicina (strain G104), which was isolated from submerged wood in a lake in Greensboro, NC. From this, six isochromenones, (R)-3,4-dihydro-4,6,8-trihydroxy-4,5-dimethyl-3-methyleneisochromen-1-one (1), (R)-3,4-dihydro-4,8-dihydroxy-6-methoxy-4,5-dimethyl-3-methyleneisochromen-1one (2), 3,8-dihydroxy-3-hydroxymethyl-6-methoxy-4,5-dimethylisochroman-1-one (3), clearanol C (4), clearanol F (5), and clearanol G (6), one isobenzofuranone (7), and two tetrahydronaphthalene derivatives [isosclerone (8) and radinaphthalenone (9)] were isolated. ${ }^{61}$ Of these, compounds 5, 6, and 9 were new. The structures were elucidated using a set of spectroscopic and spectrometric techniques, including electronic circular dichroism (ECD) measurements and timedependent density functional theory and quantum chemical ECD (TDDFT-ECD) calculations for the determination of absolute configuration. All compounds (1-9) were tested for antimicrobial activity against an array of bacteria and fungi, and 4 showed promising activity against $S$. aureus with an MIC value of $33 \mu \mathrm{g} / \mathrm{mL}$. Interestingly, $P$. radicina has been isolated from both terrestrial (root surfaces of soybean) and freshwater habitats in NC, suggesting that it may be an immigrant species. $^{61}$

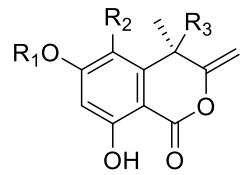

1: $\mathrm{R}_{1}=\mathrm{H}, \mathrm{R}_{2}=\mathrm{CH}_{3}, \mathrm{R}_{3}=\mathrm{OH}$

2: $\mathrm{R}_{1}=\mathrm{CH}_{3}, \mathrm{R}_{2}=\mathrm{CH}_{3}, \mathrm{R}_{3}=\mathrm{OH}$

4: $\mathrm{R}_{1}=\mathrm{CH}_{3}, \mathrm{R}_{2}=\mathrm{CH}_{3}, \mathrm{R}_{3}=\mathrm{H}$

6: $\mathrm{R}_{1}=\mathrm{CH}_{3}, \mathrm{R}_{2}=\mathrm{CH}_{2} \mathrm{OH}, \mathrm{R}_{3}=\mathrm{OH}$<smiles>COc1cc(O)c2c(c1C)[C@](C)(C(C)O)OC2=O</smiles>

7<smiles>O=C1CC[C@H](O)c2cccc(O)c21</smiles><smiles>[R2]C1(CO)OC(=O)c2c(O)cc(OC)c(C)c2[C@@]1([R2])C</smiles>

3: $\mathrm{R}_{1}=\mathrm{H}, \mathrm{R}_{2}=\mathrm{OH}$

5: $\mathrm{R}_{1}=\mathrm{OH}, \mathrm{R}_{2}=\mathrm{H}$<smiles>Cc1c(O)cc(O)c2c1C(=O)CCC2=O</smiles>

Promising bioactivity of the organic extract of the aquatic fungus Halenospora sp. (strain G87), isolated from submerged wood collected in a stream on the campus of the University of North Carolina at Greensboro, led to the identification of a series of 14 new resorcylic acid lactones (10-23) [greensporone A (10), greensporone B (11), 8,9-dihydrogreensporone A (12), dechlorogreensporone A (13), greensporone C (14), O-desmethylgreensporone C (15), 8,9-dihydrogreensporone C (16), greensporone D (17), greensporone E (18), dechlorogreensporone D (19), 8,9-dihydrogreensporone D (20), greensporone F (21), dechlorogreensporone F (22), and greensporone $\mathrm{G}(23)] .{ }^{59}$ All compounds were elucidated using spectroscopic and spectrometric techniques, and the absolute configuration of one representative member of the series, 12, was established using X-ray crystallography by incorporation of 
a heavy atom, whereas for 17-20, a modified Mosher's ester method was used. The isolated compounds, except for $\mathbf{1 7}$ and 21, were tested against the MDA-MB-435 (melanoma) and HT-29 (colon) cancer cell lines. Compound 14 was the most potent $\left(\mathrm{IC}_{50}=2.9\right.$ and $7.5 \mu \mathrm{M}$, respectively), 15 showed moderate cytotoxic activity on both cancer cell lines, and 10, 13, and 19 showed moderate activity only on MDA-MB-435 cells. ${ }^{59}$ Compound $\mathbf{1 4}$ was evaluated for its in vitro TAK1 inhibitory activity and found to be inactive. ${ }^{120}$ Interestingly, some of these structures have caught the attention of synthetic chemists, with $14,^{121,122} 13$, and $19^{123}$ being subjected to total synthesis; in those cases the characterization data between synthetic and natural compounds were in agreement. While preparing this manuscript, the total synthesis of compounds $\mathbf{2 1}$ and 22 was achieved and the absolute configuration of the stereogenic centers of the tetrahydrofuran rings was established as $(5 R, 8 R) .^{124}$ In a set of pharmacological evaluations, greensporones A (10) and C (14) were found to suppress the growth of leukemic cells via induction of apoptotic cell death. ${ }^{125,126}$ An additional point about this particular example is that there was nothing remarkable about the collection of the fungus. Members of our team were simply demonstrating collecting techniques to a group of students, and yet, a species was isolated that yielded a suite of 14 new resorcylic acid lactones. This result is supportive of our hypothesis that freshwater fungi are so understudied that new biodiversity, which potentially biosynthesize new chemical diversity, can be discovered readily.

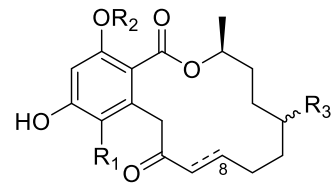

10: $\Delta^{8}, \mathrm{R}_{1}=\mathrm{Cl}, \mathrm{R}_{2}=\mathrm{CH}_{3}, \mathrm{R}_{3}=\mathrm{O}$

12: $\mathrm{R}_{1}=\mathrm{Cl}, \mathrm{R}_{2}=\mathrm{CH}_{3}, \mathrm{R}_{3}=\mathrm{O}$

13: $\Delta^{8}, \mathrm{R}_{1}=\mathrm{H}, \mathrm{R}_{2}=\mathrm{CH}_{3}, \mathrm{R}_{3}=\mathrm{O}$

14: $\Delta^{8}, \mathrm{R}_{1}=\mathrm{R}_{3}=\mathrm{H}, \mathrm{R}_{2}=\mathrm{CH}_{3}$

15: $\Delta^{8}, R_{1}=R_{2}=R_{3}=H$

16: $R_{1}=R_{3}=H, R_{2}=C_{3}$

17: $\Delta^{8}, \mathrm{R}_{1}=\mathrm{Cl}, \mathrm{R}_{2}=\mathrm{CH}_{3}, \mathrm{R}_{3}=\beta-\mathrm{OH}$

19: $\Delta^{8}, \mathrm{R}_{1}=\mathrm{H}, \mathrm{R}_{2}=\mathrm{CH}_{3}, \mathrm{R}_{3}=\beta-\mathrm{OH}$

20: $\mathrm{R}_{1}=\mathrm{Cl}, \mathrm{R}_{2}=\mathrm{CH}_{3}, \mathrm{R}_{3}=\beta-\mathrm{OH}$



11: $\Delta^{8}, \mathrm{R}=\mathrm{O}$

18: $\mathrm{R}=\beta-\mathrm{OH}$

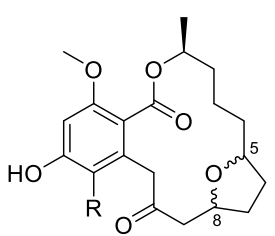

21: $(5 R, 8 R) \mathrm{R}=\mathrm{Cl}$

22: $(5 R, 8 R) \mathrm{R}=\mathrm{H}$

23: $(5 S, 8 R) \mathrm{R}=\mathrm{H}$
A systematic study of Lindgomyces madisonensis (strain G416), isolated from submerged wood collected in a stream in Madison, NC, revealed that this strain produced a series of acetophenone derivatives: madisone (24), 4'-methoxymadisone (25), dehydromadisone (26), 2" -methoxymadisone (27), dihydroallovisnaginone (28), dimadisone (29), and $4^{\prime}$ methoxydimadisone (30), from which 24, 26, 27, 29, and 30 were new natural products. ${ }^{62}$ Interestingly, by examining the chemistry of the fungus in situ using the droplet probe, ${ }^{127}$ we demonstrated that the fungus excretes and concentrates these secondary metabolites in guttates, which look like water droplets on the surface of the mycelium and appear under certain growth conditions. ${ }^{62}$ Studies of the in situ chemistry of fungi (e.g., studying where fungal metabolites are biosynthesized or stored) represent fascinating areas for further study.<smiles>[R]CCc1c(O)cc(OC)c(C(C)=O)c1O</smiles>

24: $\mathrm{R}_{1}=\mathrm{OH}, \mathrm{R}_{2}=\mathrm{H}$ 25: $\mathrm{R}_{1}=\mathrm{OH}, \mathrm{R}_{2}=\mathrm{CH}_{3}$ 26: $R_{1}=H, R_{2}=H$ 27: $\mathrm{R}_{1}=\mathrm{OCH}_{3}, \mathrm{R}_{2}=\mathrm{H}$<smiles>[R]O[R]([H])=C</smiles>

Fungal strains Clohesyomyces aquaticus (strain G100) and Clohesyomyces sp. (strain G102) were isolated from conidia on samples of submerged wood collected from Lake Brandt in Greensboro, NC. From their organic extracts, 16 (31-46) and five $(31,34,36-38)$ compounds, respectively, of which compounds 36-42 and 44-46 were new, were isolated and elucidated using a set of spectroscopic and spectrometric techniques, including a modified Mosher's ester method for the establishment of absolute configuration. These compounds are $\alpha$-pyrones [phomopsinone A (31), phomopsinone B (32), phomopsinone $\mathrm{C}$ (33), pyrenocine $\mathrm{M}$ (34), pyrenocine $\mathrm{K}$ (35), 6-hydroxy-7-epi-phomopsinone A (36), 5-deoxy-7hyrodoxypyrenocine $\mathrm{M}$ (37), pyrenocine $\mathrm{P}$ (38), 7-hyrdoxypyrenocine $M(39)$, pyrenocine $Q(40)$, pyrenocine $R$ (41), and 5-hydroxyphomopsinone A (42)], two tetrahydroxanthones, secalonic acid A (43) and 8-hydroxyblennolide $\mathrm{H}$ (44), and two monomeric hexahydroxanthones, cis-dihydro-8hydroxyblennolide $\mathrm{H}(45)$ and trans-dihydro-8-hydroxyblennolide $\mathrm{H}(46) .{ }^{60}$ Since the isolated classes of compounds had shown a diversity of biological activities, they were tested against a panel of bacteria and fungi (Staphylococcus aureus, Escherichia coli, Mycobacterium smegmatis, Candida albicans, and Aspergillus niger), but all were inactive. On the other hand, $31,32,36,38$, and $43-45$ showed moderate in vitro inhibitory activity against the essential Salmonella typhimurium bacterial peptidyl-tRNA hydrolase (Pth1); by using a chemical shift perturbation mapping assay, it was demonstrated that 43 binds allosterically to Pth $1 .{ }^{60}$

The fungal strain Helotiales sp. (strain G730) was isolated from a sample of submerged wood collected from a lake in Hanging Rock State Park, NC. Chemical investigation of a solid-phase culture of the fungus yielded three new prenylated diresorcinols, leotiomycenes A-C (47-49), along with (4R)regiolone (50) and decarboxycitrinone $(\mathbf{5 1}) .{ }^{63}$ The structures of all compounds were elucidated via NMR, HRESIMS, and Xray crystallography, and the absolute configuration of 47 was established using TDDFT-ECD calculations. In addition, all compounds showed a significant reduction in the production of AIP (autoinducing peptide) by the MRSA (methicillinresistant Staphylococcus aureus) strain $\mathrm{AH} 1263$ with $\mathrm{IC}_{50}$ values ranging from 0.3 to $12.5 \mu \mathrm{M}$. Thus, these compounds represent potential leads in the development of antivirulence therapeutics. ${ }^{63,128}$

A peak library ${ }^{129}$ of 64 freshwater fungal isolates from diverse habitats was tested against a prostate cancer cell line (E006AA-hT, prostate cancer from an African American). The most active sample displayed $20 \%$ viability when tested at a concentration of $2 \mu \mathrm{g} / \mathrm{mL}$, and this came from a Delitschia sp. 
<smiles>[R]C(C)C[Z2]1([R2])OC([R1])c2c(OC)cc(=O)oc2C1[R]</smiles>

31: $(7 S) R_{1}=R_{2}=R_{3}=H$ 32: $(7 S, 9 R) \mathrm{R}_{1}=\mathrm{R}_{2}=\mathrm{H}, \mathrm{R}_{3}=\mathrm{OH}$ 33: $(7 S, 9 S) \mathrm{R}_{1}=\mathrm{R}_{2}=\mathrm{H}, \mathrm{R}_{3}=\mathrm{OH}$ 35: $(7 R) \mathrm{R}_{1}=\mathrm{R}_{2}=\mathrm{H}, \mathrm{R}_{3}=\mathrm{O}$ 36: (7R) $\mathrm{R}_{1}=\mathrm{R}_{3}=\mathrm{H}, \mathrm{R}_{2}=\alpha-\mathrm{OH}$ 42: (7S) $\mathrm{R}_{1}=\alpha-\mathrm{OH}, \mathrm{R}_{2}=\mathrm{R}_{3}=\mathrm{H}$<smiles>COc1cc(=O)oc2c1CO[C@H](CO)C2</smiles><smiles>COc1cc(=O)oc(CO)c1C</smiles>

38<smiles>COC(=O)[C@@]12Oc3ccc(-c4ccc5c(c4O)C(=O)C4=C(O)C[C@@H](C)[C@@H](O)[C@]4(C(=O)OC)O5)c(O)c3C(=O)C1=C(O)C[C@H](C)[C@@H]2O</smiles><smiles>COC(=O)[C@]12Oc3cccc(O)c3C(=O)C1=C(O)C[C@@H](C)[C@H]2O</smiles>

44<smiles>[R]c1c(C)cc2c(c1O)C(C=C(C)C)c1c(O)cc(C)cc1O2</smiles>

47: $(9 S) \mathrm{R}=\mathrm{COOH}$ 49: $\mathrm{R}=\mathrm{H}$<smiles>O=C1CC[C@H](O)c2cccc(O)c21</smiles>

50

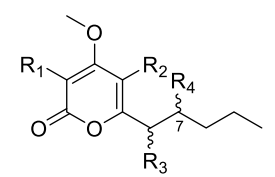

34: $\mathrm{R}_{1}=\mathrm{H}, \mathrm{R}_{2}=\mathrm{CH}_{2} \mathrm{OH}, \mathrm{R}_{3}=\mathrm{R}_{4}=\mathrm{H}$ 37: (7R) $\mathrm{R}_{1}=\mathrm{H}, \mathrm{R}_{2}=\mathrm{CH}_{3}, \mathrm{R}_{3}=\mathrm{H}, \mathrm{R}_{4}=\mathrm{OH}$ 39: $\mathrm{R}_{1}=\mathrm{H}, \mathrm{R}_{2}=\mathrm{CH}_{2} \mathrm{OH}, \mathrm{R}_{3}=\mathrm{H}, \mathrm{R}_{4}=\mathrm{OH}$ 40: $R_{1}=\mathrm{CH}_{3}, \mathrm{R}_{2}=\mathrm{H}, \mathrm{R}_{3}=\mathrm{OH}, \mathrm{R}_{4}=\mathrm{H}$

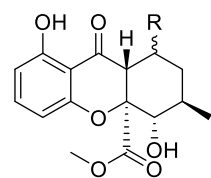

45: $\mathrm{R}=\alpha-\mathrm{OH}$ 46: $\mathrm{R}=\beta-\mathrm{OH}$<smiles>CC(C)=CCc1c(O)cc(C)cc1Oc1cc(C)c(C(=O)O)c(O)c1</smiles><smiles>Cc1oc(=O)c2c(O)cc(O)c(C)c2c1C</smiles>

51 (strain G858), which was isolated from submerged wood collected in LeBaup stream in Ariége, Rimont, France, in 2015. Bioactivity-directed fractionation led to a series of new (52-58 and 65) and known polyketides (59-64), specifically, delitpyrone A (52), 1', $2^{\prime}$-epoxi-delitpyrone A (53), delitpyrone B (54), delitpyrone C (55), 2'-oxodelitpyrone A (56), delitpyrone D (57), delitpyrone E (58), 5-(3-S-hydroxybutyl)-4-methoxy-6-methyl-2H-pyran-2-one (59), 5-(3-oxobutyl)-4-methoxy-6-methyl-2H-pyran-2-one (60), pyrenocine I (61), 3'-hydroxydelitpyrone D (62), 5-butyl-6-(hydroxymethyl)-4-methoxy-2H-pyran-2-one (63), 6-ethyl-2,7-dimethoxyjuglone (64), and $3 S^{*}, 4 S^{*}$-7-ethyl-4,8-dihydroxy-3,6-dimethoxy3,4-dihydronaphthalen-1 $(2 H)$-one $(65){ }^{64}$ All compounds were characterized using a set of spectroscopic and spectrometric methods, and the absolute configuration of the most abundant member of each subclass of compounds was assigned through a modified Mosher's ester method. ${ }^{64}$<smiles>[R]C(C)C([R])[C@H]([R])c1c(OC)cc(=O)oc1C</smiles>

52: (1' $S) \mathrm{R}_{1}=\mathrm{OH}, \mathrm{R}_{2}=\mathrm{R}_{3}=\mathrm{H}$ 54: $\left(1^{\prime} R, 2^{\prime} S\right) R_{1}=R_{2}=O H, R_{3}=H$ 56: (1'R) $\mathrm{R}_{1}=\mathrm{OH}, \mathrm{R}_{2}=\mathrm{O}, \mathrm{R}_{3}=\mathrm{H}$ 57: $\mathrm{R}_{1}=\mathrm{R}_{3}=\mathrm{H}, \mathrm{R}_{2}=\mathrm{O}$ 58: $\left(2^{\prime} S\right) R_{1}=R_{3}=H, R_{2}=O H$ 59: (3'S) $\mathrm{R}_{1}=\mathrm{R}_{2}=\mathrm{H}, \mathrm{R}_{3}=\mathrm{OH}$ 60: $R_{1}=R_{2}=H, R_{3}=O$ 62: (3'S) $\mathrm{R}_{1}=\mathrm{H}, \mathrm{R}_{2}=\mathrm{O}, \mathrm{R}_{3}=\mathrm{OH}$<smiles>CCC1OC1c1c(OC)cc(=O)oc1C</smiles><smiles>C=c1oc(=O)cc(OC)/c1=C/C[C@H](O)CC</smiles>

53<smiles>[R]c1oc(=O)cc(OC)c1/C=C/C([R2])C</smiles>

61: $\Delta^{1},\left(3^{\prime} S\right) \mathrm{R}_{1}=\mathrm{CH}_{3}, \mathrm{R}_{2}=\mathrm{OH}$ 63: $\mathrm{R}_{1}=\mathrm{CH}_{2} \mathrm{OH}, \mathrm{R}_{2}=\mathrm{H}$<smiles>CCc1c(OC)cc2c(c1O)C(=O)C=C(OC)C2=O</smiles>

64<smiles>CCc1c(OC)cc2c(c1O)C(=O)C[C@@H](OC)[C@H]2O</smiles>

Two known aromatic polyketides, isosclerone (8) and sphaerolone (66), were isolated and identified from the organic extract of Minutisphaera parafimbriatispora (strain G156-4). ${ }^{87}$ The fungus was collected in 2013 from submerged wood in Big Beaver Island Creek, in Madison, NC. ${ }^{87}$ Compounds 8 and 66 were tested for antimicrobial activity against an array of bacteria and fungi. Compound $\mathbf{6 6}$ showed moderate activity against Staphylococcus aureus and Mycobacterium smegmatis with MIC values of 86 and $172 \mu \mathrm{M}$, respectively. ${ }^{87}$<smiles>O=C1C[C@@]2(O)Oc3cc(=O)c4c(O)cccc4c2c3-c2cccc(O)c21</smiles>

Investigations conducted by other research groups include the following. From the fungus Wicklowia aquatica (strain F761), obtained from herbaceous material collected from a backwater swamp in the Ocala National Forest in northern Florida, the polyketides tetrahydroepiheveadride (67), dideoxoepiheveadride (68), deoxodihydroepiheveadride (69), epiheveadride (70), deoxoepiheveadride (71), dihydroepiheveadride (72), and waquafranones A (73) and B (74) along with the depsidone folipastatin (75) and the depside agonodepside B (76) were isolated and characterized. ${ }^{130}$ Compounds 67-69, 73, and 74 were new. Here is yet another example where a newly described genus and species (i.e., $W$. aquatica) afforded new chemistry in the form of these interesting nonadride analogues.

Chemical investigations of the fungus Xylomyces chlamydosporus (strain H58-1), isolated from a sample of submerged wood that was collected from a stream in the Great Smoky Mountains National Park, afforded two new compounds, 9,10dihydro-3-epi-radicinol (77) and (2S,3S)-3,7-dihydroxy-2,5dimethylchroman-4-one (78), along with the known compounds 3-epi-radicinol (79), radicinol (80), 4-epi-radicinol (81), 3-epi-radicinol epoxide (82), radicinin (83), and 3-epiradicinin (84). In a disk diffusion assay, 83 and 84 were active 


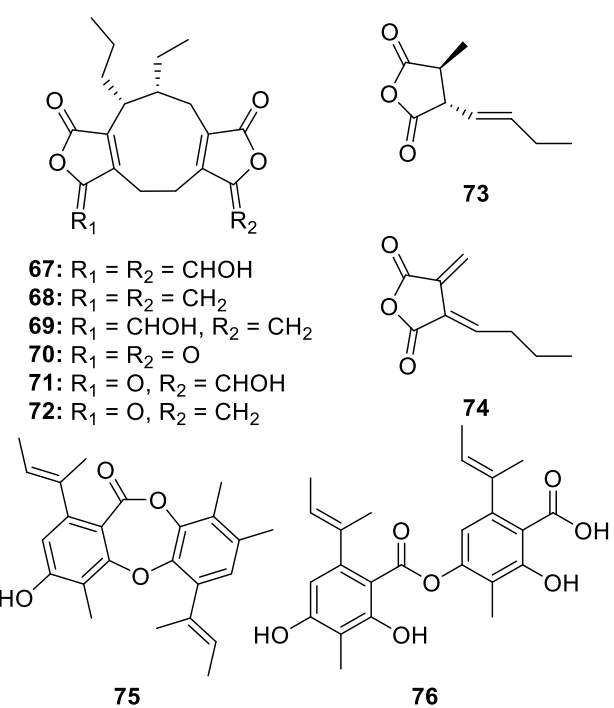

against Fusarium verticillioides (NRRL 25457), causing zones of 27 and $21 \mathrm{~mm}$ when tested at $100 \mu \mathrm{g} /$ disk, respectively. ${ }^{131}$ Interestingly, $X$. chlamydosporus belongs to the ascomycete order Jahnulales (an exclusively aquatic order), ${ }^{132}$ and this study was the first to explore the chemistry of this understudied genus.<smiles>[R]C1c2cc(/C=C/C)oc(=O)c2C([R])[C@@H](C)OC1C</smiles><smiles>Cc1cc(O)cc2c1C(=O)C(O)[C@H](C)O2</smiles>

$$
\begin{aligned}
& \text { 77: } \mathrm{R}_{1}=\mathrm{R}_{2}=\alpha-\mathrm{OH} \\
& \text { 79: } \Delta^{9}, \mathrm{R} 1=\mathrm{R}_{2}=\alpha-\mathrm{OH} \\
& \text { 80: } \Delta^{9}, \mathrm{R} 1=\alpha-\mathrm{OH}, \mathrm{R}_{2}=\beta-\mathrm{OH} \\
& \text { 81: } \Delta^{9}, \mathrm{R} 1=\mathrm{R} 2=\beta-\mathrm{OH} \\
& \text { 83: } \Delta^{9}, \mathrm{R} 1=\mathrm{O}, \mathrm{R}_{2}=\beta-\mathrm{OH} \\
& \text { 84: } \Delta^{9}, \mathrm{R} 1=\mathrm{O}, \mathrm{R}_{2}=\alpha-\mathrm{OH}
\end{aligned}
$$<smiles>CC1OC1c1cc2c(c(=O)o1)[C@@H](O)[C@H](O)[C@H](C)O2</smiles>

From the culture broth of the fungal strain Delitschia corticola (strain YMF 1.01111) isolated from a submerged woody substrate collected in Yunnan Province, China, two new metabolites were isolated: $\left(3 S^{*}, 4 S^{*}, 5 S^{*}, 6 R^{*}\right)-4,5,6$-trihydroxy-3-methyl-3,4,6,7-tetrahydro- $1 H$-isochromen-8(5H)-one (85) and ( $\left.3 R^{*}, 4 S^{*}\right)$-7-ethyl-3,4,6,8-tetrahydroxy-3,4-dihydronaphthalen-1 $(2 \mathrm{H})$-one $(\mathbf{8 6})$, together with three known ones, 6-ethyl-7-hydroxyl-2-methoxyjuglone (87), 6-ethyl-2,7-dimethoxyjuglone (64), and 6-(1-hydroxyethyl)-2,7-dimethoxyjuglone (88). ${ }^{133}$ All compounds were found to be active against three fungal strains, Alternaria sp., Sclerotium sp., and Fusarium sp., and three bacterial strains, Bacillus cereus, B. laterosporus, and Staphylococcus aureus in standard disk assays at $50 \mu \mathrm{g} /$ disk. In addition, $\mathbf{8 5}$ exhibited activity against Fusarium graminearum (Gibberella saubinetii) and Colletotrichum sp. ${ }^{133}$<smiles>C[C@@H]1OCC2=C([C@H](O)[C@@H](O)CC2=O)[C@@H]1O</smiles><smiles>[R]C1=CC(=O)c2cc(C([R4])C)c([R])cc2C1[R]</smiles>

86: $\mathrm{R}_{1}=\beta-\mathrm{OH}, \mathrm{R}_{2}=\beta-\mathrm{OH}, \mathrm{R}_{3}=\mathrm{OH}, \mathrm{R}_{4}=\mathrm{H}$ 87: $\Delta^{2}, \mathrm{R}_{1}=\mathrm{OCH}_{3}, \mathrm{R}_{2}=\mathrm{O}, \mathrm{R}_{3}=\mathrm{OH}, \mathrm{R}_{4}=\mathrm{H}$ 88: $\Delta^{2}, R_{1}=\mathrm{OCH}_{3}, \mathrm{R}_{2}=\mathrm{O}, \mathrm{R}_{3}=\mathrm{OCH}_{3}, \mathrm{R}_{4}=\mathrm{OH}$

The organic extract of the solid-substrate fermentation culture of Chaetomium sp. (strain YMF 1.02105), isolated from the submerged wood collected from the Bailong River in

Kunming, Yunnan Province, China, showed activity against $S$. aureus (ATCC 6538) and on the growth of the cancer cell lines A549 and MCF-7. ${ }^{134}$ From this, six new compounds were isolated and characterized [chaetones A-F (89-94)], along with three known ones [1-hydroxy-6-methyl-8-hydroxymethylxanthone (95), citreorosein (96), and emodin (97)]. Compound 91 showed cytotoxicity against a series of cancer cell lines, and although their data were reported in $\mu \mathrm{g} / \mathrm{mL}$, an exemplary $\mathrm{IC}_{50}$ value of $3.8 \mu \mathrm{M}$ was observed vs A549 cells. Compound 94 was about 7 times less potent, with an $\mathrm{IC}_{50}$ value of $28.1 \mu \mathrm{M}$ vs the same cells, suggesting the importance of the hydroxy and methoxy groups for cytotoxic activity. In addition, compounds 90-94 showed antibacterial activity against $S$. aureus (ATCC 6538) when tested at $50 \mu \mathrm{g} /$ disk in standard disk assays, affording inhibitory zones ranging from 11 to $15 \mathrm{~mm} .^{134}$ These compounds were new members of the dibenzo $[b, e]$ oxepinone class of secondary metabolites.



89: $\mathrm{R}_{1}=\mathrm{H}, \mathrm{R}_{2}=\mathrm{H}, \mathrm{R}_{3}=\mathrm{H}, \mathrm{R}_{4}=\mathrm{CH}_{3}$ 90: $\mathrm{R}_{1}=\mathrm{CH}_{3}, \mathrm{R}_{2}=\mathrm{H}, \mathrm{R}_{3}=\mathrm{OCH}_{3}, \mathrm{R}_{4}=\mathrm{CH}_{3}$ 91: $\mathrm{R}_{1}=\mathrm{CH}_{3}, \mathrm{R}_{2}=\mathrm{OH}, \mathrm{R}_{3}=\mathrm{OCH}_{3}, \mathrm{R}_{4}=\mathrm{CH}_{3} \quad$ 97: $\mathrm{R}_{1}=\mathrm{OH}, \mathrm{R}_{2}=\mathrm{CH}_{2} \mathrm{OH}, \mathrm{R}_{3}=\mathrm{OH}$ 92: $R_{1}=H, R_{2}=H, R_{3}=O H, R_{4}=C_{3}$

93: $\mathrm{R}_{1}=\mathrm{CH}_{3}, \mathrm{R}_{2}=\mathrm{H}, \mathrm{R}_{3}=\mathrm{OCH}_{3}, \mathrm{R}_{4}=\mathrm{CH}_{2} \mathrm{OH}$

94: $R_{1}=H, R_{2}=O H, R_{3}=H, R_{4}=\mathrm{CH}_{2} \mathrm{OH}$

Four new maleic anhydride derivatives, tricladolides $\mathrm{A}-\mathrm{D}$ (98-101), and three new alkylidene succinic acid derivatives, tricladic acids A-C (102-104), were obtained from the hyphomycete Tricladium castaneicola (strain AJ117567), isolated from leaf litter in a mountain stream in Hakone, Kanagawa, Japan. ${ }^{55}$ All compounds showed inhibitory activity against Phytophthora sp., a plant pathogen of oomycetes. ${ }^{55}$ While these structures and bioassay results are not promising from a drug discovery perspective, this is one of only a few studies that have focused on aquatic hyphomycetes, and it will be interesting to see what other structural classes emerge if/ when this ecological assembly is studied in more detail in the future.

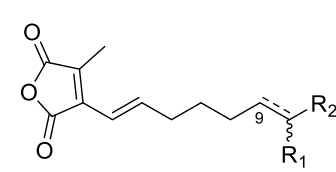

98: $\Delta^{9}, \mathrm{R}_{1}=\mathrm{H}, \mathrm{R}_{2}=\mathrm{COOH}$ 99: $\Delta^{9}, \mathrm{R}_{1}=\mathrm{H}, \mathrm{R}_{2}=\mathrm{CH}_{2} \mathrm{OH}$ 100: $\mathrm{R}_{1}=\mathrm{OH}, \mathrm{R}_{2}=\mathrm{CH}_{3}$ 101: $\mathrm{R}_{1}=\mathrm{H}, \mathrm{R}_{2}=\mathrm{CH}_{3}$

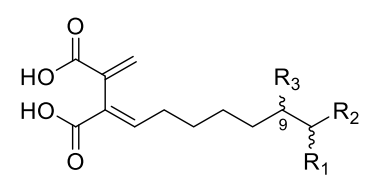

102: $\mathrm{R}_{1}=\mathrm{OH}, \mathrm{R}_{2}=\mathrm{CH}_{3}, \mathrm{R}_{3}=\mathrm{H}$ 103: (9S) $\mathrm{R}_{1}=\mathrm{H}, \mathrm{R}_{2}=\mathrm{CH}_{3}, \mathrm{R}_{3}=\mathrm{OH}$ 104: $\mathrm{R}_{1}=\mathrm{H}, \mathrm{R}_{2}=\mathrm{CH}_{2} \mathrm{OH}, \mathrm{R}_{3}=\mathrm{H}$
An extract of the fungus Phoma sp. (strain TPU1222), isolated from a freshwater sample collected at Hayakake Lake, Aomori, Japan, yielded the new compound 1-methoxy-3,5'dimethyl-2,3'-oxybiphenyl-5, $1^{\prime}, 2^{\prime}$-triol (105), along with three known ones [5-methoxy-3,5'-dimethyl-2,3'-oxybiphenyl$1,1^{\prime}, 2^{\prime}$-triol (106), cyperine (107), and 6-methylsalicylic acid (108)]. ${ }^{135}$ Compounds 105-108 were evaluated for their inhibitory activity against tyrosine phosphatase 1B (PTP1B). Compounds 105 and 107 exhibited inhibitory activities in a dose-dependent manner with $\mathrm{IC}_{50}$ values of 13 and $17 \mu \mathrm{M}$, respectively. Alternatively, 106 showed $32 \%$ inhibition of the enzyme at $36 \mu \mathrm{M}$, and 108 was inactive at $66 \mu \mathrm{M} .^{135}$ 
<smiles>[R6]Oc1cc([R6])c(Oc2cc(C)cc(O)c2[R6])c(C)c1</smiles>

105: $\mathrm{R}_{1}=\mathrm{OH}, \mathrm{R}_{2}=\mathrm{CH}_{3}, \mathrm{R}_{3}=\mathrm{H}$

106: $\mathrm{R}_{1}=\mathrm{OH}, \mathrm{R}_{2}=\mathrm{H}, \mathrm{R}_{3}=\mathrm{CH}_{3}$

107: $R_{1}=H, R_{2}=H, R_{3}=C_{3}$<smiles>Cc1cccc(O)c1C(=O)O</smiles>

The new polyketide quinaphthin (109) was obtained from the fermentation broth of the aeroaquatic fungus Helicoon richonis (strain SY034843), isolated from submerged wood from Bystock Reservoir, Devon, U.K. ${ }^{136}$ This compound showed activity against a range of Gram-positive bacteria, two wall-less bacteria, Acholeplasma laidlawii (NCTC 10116) and Mycoplasma gallisepticum (NCTC 10115), and the human protozoan pathogen Trichomonas vaginalis. Preliminary investigations have shown that $\mathbf{1 0 9}$ is more toxic than the anticancer agent doxorubicin and that it is mutagenic in S. cerevisiae strains D4 and XV185-14C. Its high level of toxicity was also detected in a mammalian tissue culture test using Chinese hamster fibroblasts. ${ }^{136}$ Helicoon richonis is reported to grow in shallow static water and was isolated from a submerged wood that was recovered in 1975 . Of the 19 species belonging to the genus Helicoon, $\mathrm{H}$. richonis is the only species that was explored for bioactive compounds to date, again illustrating the opportunities for new chemical diversity from underexplored organisms.

The strain Aspergillus sp. TPU1343 was isolated from a freshwater sample in Iriomote Island, Okinawa, Japan. The chemical study of a culture broth of the fungus furnished two new dimeric tetrahydroxanthones, namely, asperdichrome $(110)^{137}$ and secalonic acid F1, ${ }^{138}$ along with two known ones [secalonic acids $\mathrm{D}$ (111) and $\mathrm{F}(\mathbf{1 1 2}){ }^{137}$ The heterodimers 110, 112, and 113 inhibited the activity of the PTP1B with $\mathrm{IC}_{50}$ values of $6.0,9.6$, and $5.9, \mu \mathrm{M}$, respectively, while 111 (homodimer) showed reduced activity against PTP1B $(40 \%$ inhibition at $15.7 \mu \mathrm{M}) .^{137,138}$ As noted elsewhere, Aspergillus spp. are considered ubiquitous in diverse ecological environments, and this may not be a true freshwater fungus.

From a sample of freshwater sediment collected in the Selinos River, Turkey, the fungus Penicillium sp. (strain S1a1) was isolated. A chemical study of the ethyl acetate extract of a solid rice medium culture yielded three new [penitanzchroman (114) and tanzawaic acids $Y$ (115) and $Z$ (116)] and six known tanzawaic acid derivatives [arohynapene $\mathrm{A}(117)$ and tanzawaic acids A (118), B (119), E (120), M (121), and N (122)], three isochromans [(3S)-6-hydroxy-8-methoxy-3,5dimethylisochroman (123), (3S,4R)-6-hydroxy-8-methoxy3,5-dimethylisochromanol (124), and (1S,3S)-1,6-dihydroxy3,5-dimethyl-8-methoxyisochroman (125)], and two benzoquinones [anserinones A (126) and B (127) ]. ${ }^{139}$ Furthermore, investigation of the same fungus using the OSMAC (one-strain many-compounds) approach ${ }^{140}$ afforded tanzawaic acid $\mathrm{Z} 1$ (128). The in vitro antioxidant activity of this compound using the DPPH assay yielded an $\mathrm{IC}_{50}$ value of $2.8 \mu \mathrm{M}$, which is on par with the positive control, quercetin (i.e., $\mathrm{IC}_{50}$ value of 5.7



110

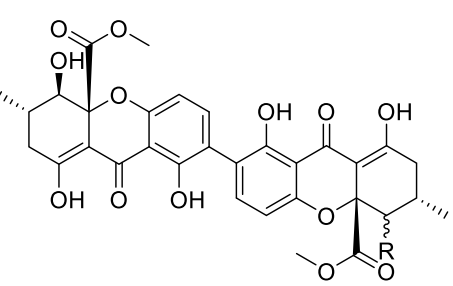

111: $\mathrm{R}=\beta-\mathrm{OH}$

112: $\mathrm{R}=\alpha-\mathrm{OH}$

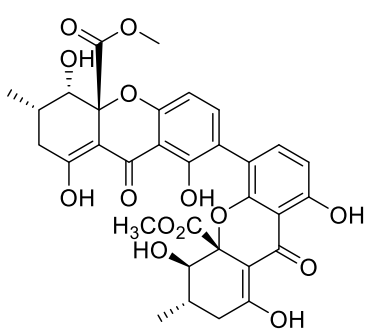

113 $\mu \mathrm{M}) .{ }^{140}$ Penicillium spp. are widespread and reported to grow in diverse habitats, including freshwater environments, and are typically classified as freshwater immigrant species.<smiles>COc1cc(O)c(C)c2c1C(Cc1ccc3c(c1/C=C/C=C/C(=O)O)C(C)CC(C)C3)OC(C)C2</smiles>

114

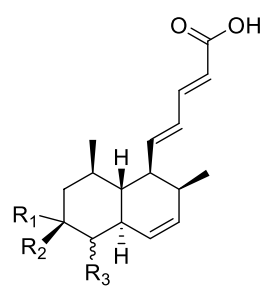

115: $\mathrm{R}_{1}=\mathrm{H}, \mathrm{R}_{2}=\mathrm{CH}_{3}, \mathrm{R}_{3}=\alpha-\mathrm{OH}$ 116: $\mathrm{R}_{1}=\mathrm{H}, \mathrm{R}_{2}=\mathrm{COOCH}_{3}, \mathrm{R}_{3}=\alpha-\mathrm{OH}$ 119: $\mathrm{R}_{1}=\mathrm{H}, \mathrm{R}_{2}=\mathrm{CH}_{3}, \mathrm{R}_{3}=\mathrm{H}$ 120: $\mathrm{R}_{1}=\mathrm{OH}, \mathrm{R}_{2}=\mathrm{CH}_{3}, \mathrm{R}_{3}=\mathrm{H}$ 121: $R_{1}=H, R_{2}=C_{2} O H, R_{3}=H$ 122: $R_{1}=H, R_{2}=C_{2} O A c, R_{3}=H$ 128: $\mathrm{R}_{1}=\mathrm{H}, \mathrm{R}_{2}=\mathrm{COOCH}_{3}, \mathrm{R}_{3}=\alpha-\mathrm{CH}_{3}$<smiles>[R]C1c2ccc(C)c(/C=C/C=C/C(=O)O)c2C(C)CC1C</smiles>

117: $\mathrm{R}=\beta-\mathrm{OH}$ 118: $\mathrm{R}=\mathrm{H}$<smiles>[R]C1O[C@H](C)C([R1])c2c(OC)cc(O)c(C)c21</smiles>

123: $R_{1}=H, R_{2}=H$ 124: $\mathrm{R}_{1}=\mathrm{H}, \mathrm{R}_{2}=\beta-\mathrm{OH}$ 125: $\mathbf{R}_{1}=\alpha-\mathrm{OH}, \mathbf{R}_{2}=\mathrm{H}$<smiles>[R]C(C)CC1=C(C)C(=O)C=C(OC)C1=O</smiles>

126: $R=O$ 127: $(9 S) \mathrm{R}=\mathrm{OH}$
The active extract of the ascomycete LL-W1278, collected from a pond in Tai Po Kau nature reserve, Hong Kong, China, produced a series of new resorcinol-containing compounds named as W1278 A-C (129-131). ${ }^{141}$ Their structures were elucidated based on spectroscopic analyses and chemical transformations, and their absolute configuration was established by acid hydrolysis and ECD analysis. Interestingly, oligomers 129-131 contain (S)-6-hydroxymellein residues as concluded from the display of the opposite ellipticity (via ECD) than that of the well-known (3R)-(-)-3,4-dihydro-6,8dihydroxy-3-methylisocoumarin. ${ }^{141}$ It is unclear what role these oligomers play for the fungus, but it is tempting to speculate that they have a structural or nutritional role.

Phenylpropanoids. Phenylpropanoids, including many $\mathrm{C}_{6}-\mathrm{C}_{1}$ compounds, ${ }^{142}$ have not been reported very frequently 

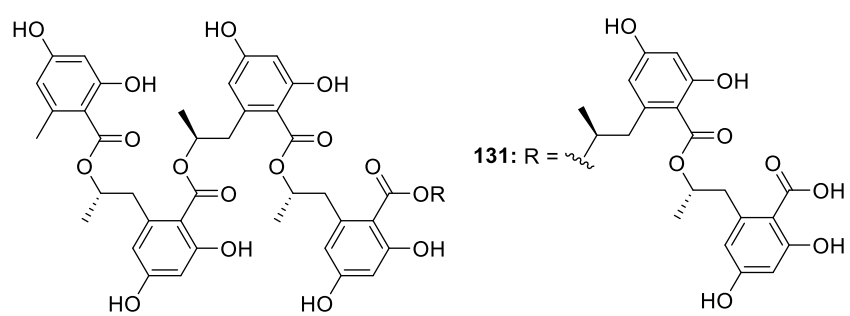

129: $\mathrm{R}=\mathrm{OH}$

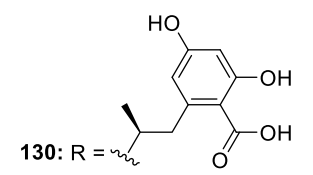

from freshwater fungi. The scale-up study of the freshwater aquatic fungus Massarina tunicata (strain A25-1), obtained from a decorticated submerged twig collected from the Lemonweir River, Adams County, WI, yielded the known compound 4-(2-hydroxybutynoxy)benzoic acid (132). ${ }^{143}$ The absolute configuration of this compound was established by systematic NMR analysis of its $R$ - and $R / S$-phenylbutyrate ester derivatives. From the same research group, the wellknown (-)-(S)-p-hydroxyphenyllactic acid (133) was isolated from the organic extracts of Annulusmagnus triseptatus (=Annulatascus triseptatus) (strain A-353-1B) obtained from submerged woody debris collected from Shaker Pond, Alfred, ME. ${ }^{144}$

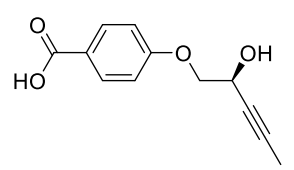

132<smiles>O=C(O)/C=C/c1ccc2c(c1)O[C@H](c1ccc(O)c(O)c1)[C@@H](CO)O2</smiles>

135<smiles>O=C(O)C(O)Cc1ccc(O)cc1</smiles>

133

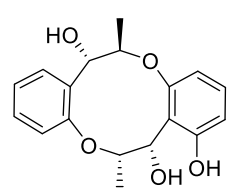

134



136

From an antifungal extract of the fungus Ophioceras dolichostomum (strain YMF1.00988), the unprecedented new neolignan ophiocerol (134), along with the known compounds isoamericanoic acid A (135) and caffeic acid (136) were isolated. This fungus was obtained from a submerged woody substrate collected from a freshwater habitat in Yunnan Province, China. ${ }^{145}$ Compounds 134-136 were tested against eight plant pathogens, Exserohilum turcicum, Fusarium sp., Paecilomyces lilacinus, Phyllosticta sp., Alternaria sp., Aspergillus niger, Coleosporium sp., and Colletotrichum sp. using a dosedependent paper-disc diffusion assay. From these, 134-136 showed moderate antifungal activity, with compound 136 being the most potent with the inhibition zones ranging from 7 to $17 \mathrm{~mm}$ at $50 \mu \mathrm{g}$ in $50 \%$ aqueous DMSO per disc. ${ }^{45}$

Terpenes. Fungi, particularly Basidiomycota, are extraordinary producers of bioactive natural products that are derived from terpenoid building blocks. ${ }^{146}$ In that context, it is somewhat surprising that there are not more examples of these types of compounds from freshwater aquatic fungi. As stated often, we postulate that this is not due to deficiencies in biosynthetic potential, but rather, simply lack of systematic investigation.
From solid-substrate fermentation cultures of the aquatic fungus Ophioceras venezuelense (strain A447-1B) collected from a fast-flowing stream at La Selva Biological Station in Heredia, Costa Rica, a new africane-type sesquiterpenoid, ophioceric acid (137), was isolated. ${ }^{147}$ While there are many natural products studies carried out on samples from the rich biodiversity of Costa Rica, there are very few aquatic fungi studied from there. Another example is the new genus and species Wicklowia aquatica, described above, ${ }^{130}$ which was isolated from a sample collected in Costa Rica. ${ }^{148}$ As noted often in this review, these findings support the great potential for uncovering new biodiversity and new chemical diversity by sampling underinvestigated regions of the world.

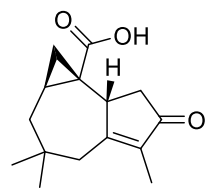

137<smiles>C=C1CCC[C@]2(C)C[C@H](O)[C@H](C(C)(C)O)C[C@@]12O</smiles>

138: $\mathrm{R}_{1}=\beta-\mathrm{OH}, \mathrm{R}_{2}=\mathrm{R}_{3}=\mathrm{R}_{4}=\mathrm{R}_{5}=\mathrm{H}$

140: $R_{1}=R_{2}=R_{3}=R_{4}=R_{5}=H$

141: $R_{1}=R_{4}=R_{5}=H, R_{2}=R_{3}=O H$

142: $\mathrm{R}_{1}=\mathrm{R}_{2}=\mathrm{R}_{3}=\mathrm{R}_{4}=\mathrm{H}, \mathrm{R}_{5}=\beta-\mathrm{OH}$

143: $R_{1}=R_{2}=R_{4}=R_{5}=H, R_{3}=O H$

144: $\mathrm{R}_{1}=\mathrm{R}_{2}=\mathrm{R}_{5}=\mathrm{H}, \mathrm{R}_{3}=\mathrm{CH}_{3}, \mathrm{R}_{4}=\beta-\mathrm{OH}$

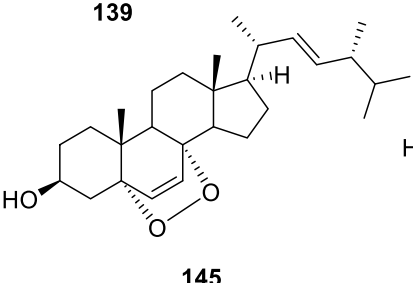

145<smiles>[R][R]([H])=C[Y16]([H])([H])O</smiles>

146: $\mathrm{R}=\mathrm{H}$
147: $\mathrm{R}=\mathrm{OH}$
Two new sesquiterpenes [rhombidiol (138) and rhombitriol (139)] along with five known ones [(-)- $\beta$-eudesmol (140), (-)-pterocarpol (141), (-)-chrysanthemol (142), (-)-longilobol (143), and (-)-5 $\beta$-hydroxy- $\beta$-eudesmol (144)] were identified from the EtOAc extract of the culture broth of Beltrania rhombica (strain T031), which was isolated from a foam sample collected at Ton-Nga-Chang Waterfall, Songkhla Province, southern Thailand. ${ }^{149}$ The isolated compounds showed weak antibacterial and antifungal activities (MIC values $>128 \mu \mathrm{g} / \mathrm{mL}$ ) against $S$. aureus ATCC25923 and C. albicans. ${ }^{149}$ Interestingly, this study utilized liquid culture fermentations with potato dextrose broth, yielding about 13 mg of 140.

The unidentified freshwater fungus YMF 1.01029, isolated from a decaying branch of an unidentified tree near Lake Fuxian in Yunnan Province, China, was subjected to a chemical investigation, yielding the terpenoid $3 \beta$-hydroxy- $5 \alpha, 8 \alpha$-epidioxyergosta-6,22-diene (145). ${ }^{150}$ Unfortunately, this compound was inactive when tested against a set of fungi and bacteria in standard disk assays. This study was included in the review because the authors mentioned the term "freshwater" in the title, but it is not entirely clear if the dead branch was submerged in or next to Lake Fuxian. Where possible, we suggest that natural products chemistry authors be as specific as possible about the collection of environmental samples, as such information could be important for follow-up research, for example in the realm of ecology.

Finally, from the fungus $W$. aquatica (strain F76-1), which was discussed in the polyketide section, the known 
sesquiterpenoids sydonic acid (146) and hydroxysydonic acid (147) were identified. ${ }^{130}$

Alkaloids and Peptides. It is well recognized that fungi, especially Ascomycota, are prolific producers of bioactive alkaloids and peptides. In our research group, the fungal strains Delitschia sp. (strain G858), Clohesyomyces sp. (strain G102), and C. aquaticus (strain G100), all described in the Polyketides section, also yielded a series of bioactive nitrogen-containing compounds. ${ }^{60,64}$ From the former, the known dithiodiketopiperazine sporidesmin A (148) and two known lipopeptides of the artrichitin type (149 and 150) were isolated and tested against E006AA-hT cells in a concentration-dependent manner. Compound 148 strongly inhibited the viability of the cells at the lowest concentration tested $(2.5 \mu \mathrm{M})$, while 149 and 150 were inactive. ${ }^{64}$ On the other hand, from the Clohesyomyces species, two known cyclodepsipeptides, Sch 378161 (151) and Sch 217048 (152), were isolated and identified by means of NMR, HRMS, and MS/MS data. ${ }^{60}$ Regrettably, these compounds were inactive against an array of bacteria and fungi.



148


Compound 148 was also found in the culture broth of Delitschia corticola (strain YMF 1.01111) isolated from a submerged woody substrate collected from a freshwater habitat in Yunnan Province, China. ${ }^{133}$ This compound showed comparable antimicrobial activity to that of the positive controls (ciclopirox and ampicillin sodium) against Fusarium graminearum (noted as Gibberella saubinetii in the manuscript), Exserohilum turcicum, Alternaria sp., Rhizoctonia solani, Sclerotium sp., Colletotrichum sp., Phyllosticta sp., Fusarium sp., B. cereus, B. laterosporus, E. coli, and S. aureus in standard disk assays at $50 \mu \mathrm{g} /$ disk. $^{133}$

Chemical analysis of the freshwater fungus Minutisphaera aspera (strain G427) resulted in isolation and characterization of four known dipeptides, cyclo-([S]-Pro-[S]-Leu) (153), cyclo-([R]-Pro-[S]-Phe) (154), cyclo-([S]-Pro-[S]-Phe) (155), and cyclo-([S]-Ala-[S]-Phe) (156), and the previously reported aromatic polyketide isosclerone $(\mathbf{8}){ }^{87}$ The fungus was collected in 2013 from submerged decorticated wood from Big Beaver Island Creek, in Madison, $\mathrm{NC}^{87}$ which is only about 40 miles from the campus of UNCG. Yet, M. aspera was identified as a new species, belonging to a new family (Minutisphaeraceae), as part of a new order (Minutisphaerales,
Dothideomycetes), ${ }^{87}$ providing further evidence that new biodiversity can be discovered readily by sampling fungi from freshwater habitats.<smiles>CC(C)C[C@H]1NC(=O)[C@@H]2CCCN2C1=O</smiles><smiles>O=C1N[C@@H](Cc2ccccc2)C(=O)N2CCC[C@H]12</smiles><smiles>O=C1N[C@H](Cc2ccccc2)C(=O)N2CCC[C@H]12</smiles><smiles>C[C@H]1NC(=O)[C@@H](Cc2ccccc2)NC1=O</smiles>

155

156

Chemical investigation of the new freshwater fungus Glarea lozoyensis, previously identified as Zalerion arboricola, ${ }^{151}$ led to the discovery of a series of new lipopeptides, specifically pneumocandins $\mathrm{A}_{1}-\mathrm{A}_{4}\left(\mathbf{1 5 7 - 1 6 0 )}, \mathrm{B}_{2}\right.$ (161), and $\mathrm{C}_{0}$ (162). ${ }^{152-155}$ This strain was recovered from filtrates of water and sediments from a farm pond in the Valle del Rio Lozoya, near Madrid, Spain, and the isolated compounds showed strong activity against Candida sp. and Pneumocystis carinii. ${ }^{152-155}$ This is the only study reported to date that explores the chemistry of freshwater fungi from Spain. The antifungal drug caspofungin, used for the treatment of lifethreatening fungal diseases, was semisynthesized from pneumocandin $\mathrm{B}_{0} \cdot{ }^{156}$ While it is not entirely clear if this should be considered a freshwater fungus, as it does not seem to have specific morphological adaptations for such a lifestyle, the order, Helotiales, to which this fungus is phylogenetically affiliated does contain several freshwater species. ${ }^{151}$

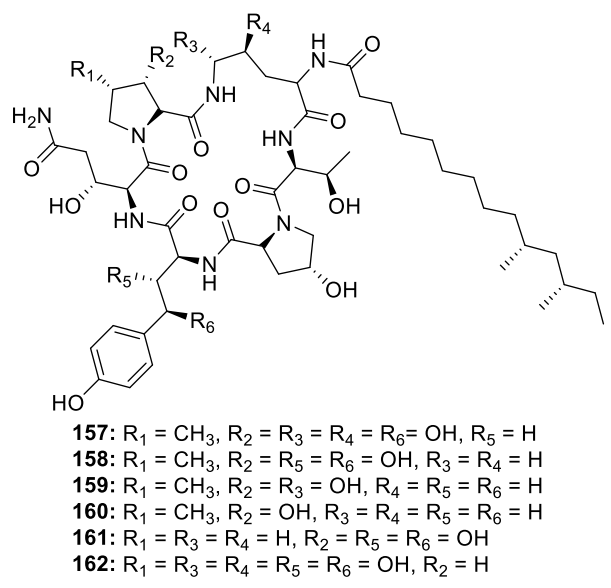

Chemical investigation of the fungal strain Aspergillus ochraceus (strain KM007) obtained from Fuxian Lake, Yunnan Province, China, led to the isolation of the novel prenylated alkaloids speramides A (163) and B (164). ${ }^{157}$ From these, 163 showed moderate activity against $P$. aeruginosa with a MIC value of $0.8 \mu \mathrm{M}$, but neither compound was active against a panel of cancer cell lines. ${ }^{157}$ There are two cautionary elements to this study. First, the authors used ITS sequence data to ascribe a species name; for Aspergillus sp., ITS may not be the best identification marker for species level identification. ${ }^{70}$ Second, it is likely that this is not a true freshwater fungus, as Aspergillus spp. are ubiquitous in nearly all environments. Regardless, the structures are interesting, especially the spiro carbon in 163. 


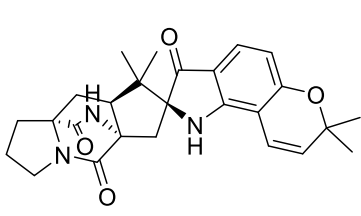

163

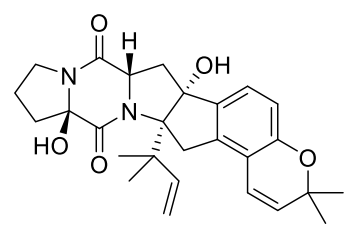

164

From Myrothecium verrucaria (strain KX138396) collected from lake water of Chenghai, Yunnan Province, China, one new quinolinone, 7-hydroxy-3-methoxyviridicatin (165), and three known ones [viridicatin (166), 3-methoxyviridicatin (167), and viridicatol (168)], along with five known benzodiazepinone alkaloids [(11aS)-2,3-dihydro- $1 H$-pyrrolo$[2,1-c][1,4]$ benzodiazepine-5,11(10H,1 laH)-dione (169), cyclopeptine (170), cyclopenin (171), dehydrocyclopeptine (172), and trans-3-(3'-hydroxybenzylidene)-3,4-dihydro-4methyl-1H-1,4-benzodiazepin-2,5-dione (173)] were isolated. $^{158}$ All compounds were tested against a panel of pathogenic bacterial strains, including B. subtilis, B. cereus, Vibrio anguillarum, and $V$. parahaemolyticus, and only 165 and 166 exhibited weak antibacterial activity $(\mathrm{MIC}=25 \mu \mathrm{M})$ against $B$. cereus, $V$. anguillarum, and $V$. parahaemolyticus, and also 165 showed inhibition activity toward B. subtilis (MIC = $25 \mu \mathrm{M}) .{ }^{158} \mathrm{M}$. verrucaria is not a true freshwater fungus and likely washed into the lake. It is widely distributed worldwide and known as a plant and nematode pathogen that was formulated as a biopesticide.<smiles>[R]Oc1c(-c2cccc([R2])c2)c2ccc([R3])cc2[nH]c1=O</smiles>

165: $\mathrm{R}_{1}=\mathrm{CH}_{3}, \mathrm{R}_{2}=\mathrm{H}, \mathrm{R}_{3}=\mathrm{OH}$

166: $R_{1}=H, R_{2}=H, R_{3}=H$

167: $\mathrm{R}_{1}=\mathrm{CH}_{3}, \mathrm{R}_{2}=\mathrm{H}, \mathrm{R}_{3}=\mathrm{H}$

168: $R_{1}=H, R_{2}=O H, R_{3}=H$



170

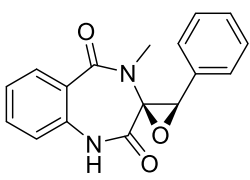

171

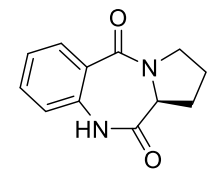

169

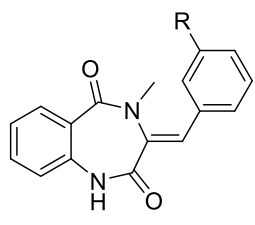

172: $\mathrm{R}=\mathrm{H}$ 173: $\mathrm{R}=\mathrm{OH}$
Recently, seven new cyclic depsipeptides, clavariopsins C-I (176-182), along with the two known congeners, clavariopsins A (174) and B (175), were isolated from the aquatic hyphomycete Clavariopsis aquatica (strain AJ117363). ${ }^{56}$ Their antifungal and cytotoxic activities were evaluated against six plant pathogenic fungi (Botrytis cinerea, Magnaporthe oryzae, Colletotrichum orbiculare, Fusarium oxysporum, A. alternata, and A. niger) and the cancer cell line HeLa-S3. The majority of the compounds exhibited potent antifungal activity against the fungi tested (minimum inhibition dose $=0.01-10 \mu \mathrm{g} / \mathrm{disk}$ ) and induced hyphal swelling in $A$. niger (minimum effective dose $=0.3-3 \mu \mathrm{g} /$ disk), whereas the compounds exhibited no cytotoxicity toward the cancer cell line. ${ }^{56}$ The collection of this sample was somewhat unique, in that aquatic fungal spores of C. aquatica were trapped from decaying leaves collected from a mountain stream at Mt. Takao in Tokyo, Japan, by air bubbles. ${ }^{159}$ The decaying leaves were immersed in $300 \mathrm{~mL}$ of water in a beaker. Fungal spores were washed out from the leaves by bubbling air at the bottom of the beaker $(1 \mathrm{~L} / \mathrm{min})$ for $1 \mathrm{~h}$. The strain was then harvested from the foam by singlecell manipulation using a micromanipulator. ${ }^{159}$



174: $A A^{2}=P i p, R_{1}=C_{3}, R_{2}=C_{3}$ 175: $A A^{2}=P i p, R=H, R_{2}=C_{3}$ 176: $A A^{2}=P i p, R=\mathrm{CH}_{3}, \mathrm{R}_{2}=\mathrm{H}$ 181: $A A^{2}=$ L-Pro, $\mathrm{R}=\mathrm{CH}_{3}, \mathrm{R}_{2}=\mathrm{CH}_{3}$

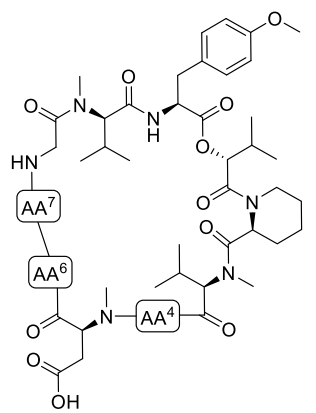

177: $\mathrm{AA}^{7}=\mathrm{L}-$ Melle, $A A^{6}=\mathrm{L}-\mathrm{MeVal}, \mathrm{AA}^{4}=\mathrm{L}-\mathrm{Val}$ 178: $A A^{7}=L-M e V a l, A A^{6}=L-M e l l e, A A^{4}=L-V a l$ 179: $A A^{7}=L-M e l l e, A A^{6}=L-M e L e u, A A^{4}=L-V a l$ 180: $\mathrm{AA}^{7}=\mathrm{L}-\mathrm{MeLeu}, A A^{6}=\mathrm{L}-$ Melle, $A A^{4}=\mathrm{L}-\mathrm{Va}$ 182: $A A^{7}=L-M e l l e, A A^{6}=L-M e l l e, A A^{4}=L-L e u$
Unclassified Secondary Metabolites. Four new tetrahydropyran derivatives called ophiocerins A-D (183-186) were isolated from cultures of the aquatic fungus Ophioceras venezuelense (strain A447-1B) collected from a fast-flowing stream at La Selva Biological Station in Heredia, Costa Rica. ${ }^{149}$ The compounds could arise biosynthetically from either a polyketide or a monosaccharide origin.

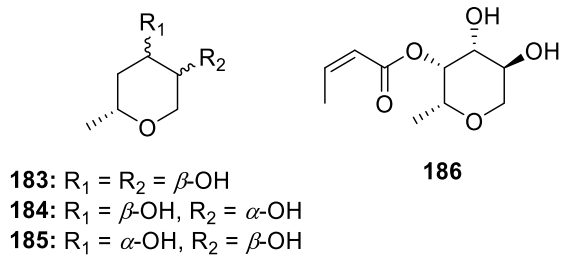

Unpublished Secondary Metabolites from Freshwater Fungi. As part of an ongoing project in the Oberlies Lab to explore the chemistry of freshwater fungi, a set of compounds have been isolated and identified, but never published. However, since these compounds were never reported from freshwater fungi, and they are all known compounds, we sought to include them in the current review. In all cases, the spectroscopic data (i.e., NMR and mass spectrometry data) for the isolated fungal metabolites were in agreement with literature values.

Two polyketides, diorcinol (187) ${ }^{160}$ and 2-hydroxy-4-(3hydroxy-5-methylphenoxy)-6-methylbenzoic acid (188), ${ }^{161}$ were isolated from the freshwater fungus Helicascus elaterascus (strain G140) that was collected from Lake Brandt in Greensboro, NC, in 2011.

The polyketide 10-norparvulenone $(\mathbf{1 8 9})^{162}$ was isolated from an unidentified fungus (strain G860) that was collected from submerged wood in the Mississippi River, near New Orleans, LA, in 2016.

From an unknown, asexual sp. (strain G369), one prenylated polyketide, penicillide (also known as vermixocin A) (190), ${ }^{163}$ and two meroterpenoids, neosetophomone B (191) and eupenifeldin (192), ${ }^{164}$ along with the known polyketide isosclerone (8), were isolated and identified. The fungus was collected from a dry streambed at Pilot Mountain State Park, $\mathrm{NC}$, in 2012.

A new natural pyrrole-containing compound that was reported elsewhere by synthesis, namely, 1-(3,4,5-trimethyl- 
<smiles>[R16]c1[nH]c(C)c(C)c1C(C)=O</smiles>

$1 H$-pyrrol-2-yl)ethan-1-one (193), ${ }^{165}$ and the sesquiterpene $(-)$-sclerosporin $(\mathbf{1 9 4})^{166}$ were isolated from a Dactylaria sp. (strain G372) that was collected from submerged wood in a stream on the campus of the University of North Carolina at Greensboro, NC, in 2012.

Using our in-house previously reported dereplication protocol, ${ }^{167}$ five compounds were tentatively identified from a Hypocreales sp. (strain G421) that was collected in Madison, $\mathrm{NC}$, in 2013. Of the identified compounds, two were polypeptides [acuminatum B (195) and acuminatum C (196)], one was a polyketide [aerofusarin (197)], and two were tetramic acid derivatives [equisetin (198) and 5'epiequisetin (199)]. Using the same dereplication methodology, compounds 195 and 197-199 were tentatively identified from Helicascus elaterascus (strain G140) that was collected from Lake Brandt, Greensboro, NC, in 2011.
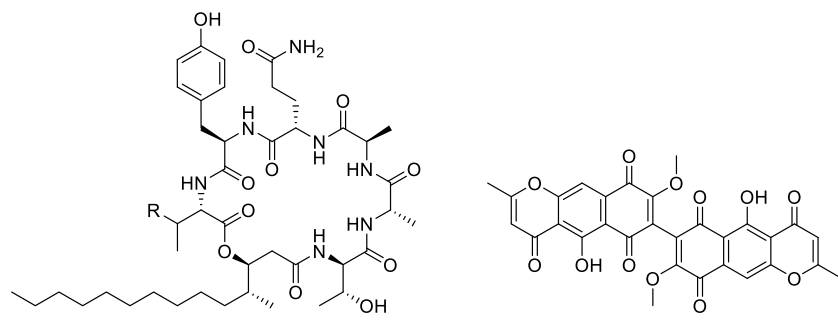

195: $\mathrm{R}=\mathrm{CH}_{2} \mathrm{CH}_{3}$ 196: $\mathrm{R}=\mathrm{CH}_{3}$

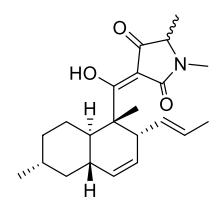

198: $\mathrm{R}=\beta-\mathrm{CH}_{2} \mathrm{OH}$

199: $\mathrm{R}=\alpha-\mathrm{CH}_{2} \mathrm{OH}$

\section{CONCLUSIONS}

Over 280 freshwater fungal metabolites have been published since 1992, and 199 of those were in the past decade. Since this ecological group is understudied, we believe this number represents only a subfraction of freshwater fungal chemistry, and as noted in Figure 6, large swaths of the world's fresh water has not been studied, notably throughout South America, Africa, and large portions of Asia. Bioactive compounds produced by freshwater fungi against a myriad of different biological assays suggest potential from the point of view of drug discovery. In addition, given the importance of fresh water for all life on Earth, the ecological relevance of these fungi and their bioactive metabolites could be substantial. The emergence of genome sequencing platforms will allow us to gain insight into the biosynthetic gene clusters from freshwater fungi, thereby enabling us to capture secondary metabolites of varied diversity. Also, further systematic studies on these organisms are needed to understand species identities, ecological roles, and evolution. Indeed, this ecological group of fungi may provide a treasure trove of hidden chemical diversity awaiting discovery.

Table 1. Glossary of Mycology and Ecology Terms

\begin{tabular}{|c|c|}
\hline Term & Definition \\
\hline $\begin{array}{l}\text { Aeroaquatic } \\
\text { hyphomycetes }\end{array}$ & $\begin{array}{l}\text { Asexual fungi that form spores (i.e., conidia) when substrates are exposed } \\
\text { to air. The conidia of these fungi are hydrophobic and morphologically } \\
\text { adapted to trap air and/or float. These fungi are adapted for habitats with } \\
\text { fluctuating levels of water and for emergent substrates such as dead wood. }\end{array}$ \\
\hline Apothecia & $\begin{array}{l}\text { The cup shaped fruiting body of the fungus in the Discomycetes } \\
\text { (Leotiomycetes) in the phylum Ascomycota. Singular - Apothecium; plural } \\
\text { - Apothecia }\end{array}$ \\
\hline Ascospores & $\begin{array}{l}\text { Spore formed in ascomycetes because of sexual reproduction. Ascospores } \\
\text { occur in a sac-like structure called the ascus. }\end{array}$ \\
\hline Asci & $\begin{array}{l}\text { The "spore sack" of an ascomycete fungus. An ascus usually contains } 8 \\
\text { ascospores; sometimes it could be a multiple of } 8 \text {, such as } 16,32,64 \\
\text { ascospores. Singular - ascus; plural - asci. }\end{array}$ \\
\hline Ascoma & $\begin{array}{l}\text { The fruiting body of fungi in the ascomycetes. Singular - ascoma; plural - } \\
\text { ascomata. Also referred to as the ascocarp. }\end{array}$ \\
\hline Ascomal cavity & The inside of the fruiting body of ascomycetes. \\
\hline Bitunicate & $\begin{array}{l}\text { The term is applied to asci of the Loculoascomycetes (Dothideomycetes). } \\
\text { Refers to an ascus that has two functional layers, i.e., an outer ectoascus } \\
\text { and inner endoascus. }\end{array}$ \\
\hline Conidiophore & A hypha or a stalk that bears a conidiogenous cell that makes the conidia. \\
\hline Coelomycetes & $\begin{array}{l}\text { Asexual fungi that form conidia in a cavity called pycnidia. Although } \\
\text { sometimes pycnidia resemble ascoma in overall morphology, they are } \\
\text { asexual structures without asci and ascospores. }\end{array}$ \\
\hline Conidia & $\begin{array}{l}\text { Spores formed in the ascomycetes because of asexual reproduction. } \\
\text { Conidia occur on tips of specialized hyphae called conidiogenous cells or } \\
\text { arise directly from the mycelia and as in the case of yeasts, conidia arise by } \\
\text { budding }\end{array}$ \\
\hline Deliquescent asci & $\begin{array}{l}\text { The process of becoming fluid. Some asci of aquatic ascomycetes } \\
\text { breakdown their wall at maturity and are referred to as possessing } \\
\text { deliquescent asci. }\end{array}$ \\
\hline Lotic & Running bodies of water such as streams, brooks, and rivers. \\
\hline Lentic & Standing bodies of water such as lakes, swamps, and bogs. \\
\hline $\begin{array}{l}\text { Meiosporic or } \\
\text { Teleomorph }\end{array}$ & $\begin{array}{l}\text { Forming spores by the process of meiosis (spores made via sexual } \\
\text { reproduction). }\end{array}$ \\
\hline $\begin{array}{l}\text { Mitosporic or } \\
\text { Anamorph }\end{array}$ & $\begin{array}{l}\text { Forming spores by the process of mitosis (spores made via asexual } \\
\text { reproduction). }\end{array}$ \\
\hline Perithecia & $\begin{array}{l}\text { Small, sack-like, or flask-like fruiting bodies of several types of } \\
\text { ascomycetes. Singular - perithecium; plural -perithecia. }\end{array}$ \\
\hline Pseudoparaphyses & $\begin{array}{l}\text { Many sterile threads inside a pseudothecium (they can be septate or } \\
\text { aseptate). Singular - pseudoparaphysis; plural - pseudoparaphyses. }\end{array}$ \\
\hline $\begin{array}{l}\text { Riparian } \\
\text { vegetation }\end{array}$ & Plants and tree communities growing along river and lake margins \\
\hline Sigmoidal & $\begin{array}{l}\text { Having "S"-shaped structure. Used in reference to aquatic hyphomycetes } \\
\text { or Ingoldian fungi conidia or spores. }\end{array}$ \\
\hline Tetraradiate & $\begin{array}{l}\text { Having four arms radiating from the center. Used in reference to aquatic } \\
\text { hyphomycetes or Ingoldian fungi conidia or spores. }\end{array}$ \\
\hline Unitunicate & $\begin{array}{l}\text { Refers to an ascus having a single functional layer, i.e., asci that are not } \\
\text { separating. }\end{array}$ \\
\hline
\end{tabular}

\section{ASSOCIATED CONTENT}

\section{Supporting Information}

The Supporting Information is available free of charge at https://pubs.acs.org/doi/10.1021/acs.jnatprod.0c01340.

Table of sequenced genomes of freshwater fungi (Ascomycota) (PDF) 


\section{AUTHOR INFORMATION}

\section{Corresponding Authors}

Tamam El-Elimat - Department of Medicinal Chemistry and Pharmacognosy, Faculty of Pharmacy, Jordan University of Science and Technology, Irbid 22110, Jordan; (1) orcid.org/ 0000-0002-9246-4974; Email: telimat@just.edu.jo

Nicholas H. Oberlies - Department of Chemistry and Biochemistry, University of North Carolina at Greensboro, Greensboro, North Carolina 27402, United States; (1) orcid.org/0000-0002-0354-8464; Email: nicholas_oberlies@uncg.edu

\section{Authors}

Huzefa A. Raja - Department of Chemistry and Biochemistry, University of North Carolina at Greensboro, Greensboro, North Carolina 27402, United States; (1) orcid.org/00000002-0824-9463

Mario Figueroa - Departamento de Farmacia, Facultad de Química, Universidad Nacional Autónoma de México, Ciudad de México 04510, Mexico; ○ orcid.org/0000-00017004-0591

Ahmed H. Al Sharie - Faculty of Medicine, Jordan University of Science and Technology, Irbid 22110, Jordan

Rick L. Bunch - Department of Geography, Environment, and Sustainability, University of North Carolina at Greensboro, Greensboro, North Carolina 27402, United States

Complete contact information is available at:

https://pubs.acs.org/10.1021/acs.jnatprod.0c01340

\section{Notes}

The authors declare the following competing financial interest(s): N. H. Oberlies is a member of the Scientific Advisory Board of Mycosynthetix, Inc.

\section{ACKNOWLEDGMENTS}

T.E. acknowledges the partial financial support by Deanship of Research, Jordan University of Science and Technology, Irbid, Jordan (Grant No. 38/2018). M.F. acknowledges the partial financial support by grants from UNAM-DGAPA IN222220 and FQ-PAIP 5000-9145. Research on fungi in the Oberlies' lab is supported in part by the NIH/National Cancer Institute under Grant P01 CA125066. We thank Tyler Graf from UNCG for helpful discussions.

\section{REFERENCES}

(1) Bills, G. F.; Gloer, J. B. Microbiology Spectrum 2016, 4.

(2) Heitman, J.; Howlett, B. J.; Crous, P. W.; Stukenbrock, E. H.; James, T. Y.; Gow, N. A. The Fungal Kingdom; John Wiley \& Sons, 2017; Vol. 35, p 1136.

(3) Shearer, C. A.; Raja, H. A. Freshwater Ascomycetes and their anamorphs. http://fungi.life.illinois.edu/ (Accessed June 22, 2020).

(4) Shearer, C. A. Nova Hedwigia 1993, 56, 1-33.

(5) Shearer, C. A. The Distribution of Freshwater Filamentous Ascomycetes. In Trichomycetes and Other Fungal Groups, 1st ed.; Misra, J. K., Ed.; CRC Press: Boca Raton, 2001; pp 225-292.

(6) Jones, E. G.; Hyde, K. D.; Pang, K.-L. Freshwater Fungi: and Fungal-like Organisms; Walter de Gruyter GmbH \& Co KG: Boston, 2014; p 496.

(7) Grossart, H.-P.; Van den Wyngaert, S.; Kagami, M.; Wurzbacher, C.; Cunliffe, M.; Rojas-Jimenez, K. Nat. Rev. Microbiol. 2019, 17, 339-354.

(8) Pang, K.-L.; Overy, D. P.; Jones, E. G.; da Luz Calado, M.; Burgaud, G.; Walker, A. K.; Johnson, J. A.; Kerr, R. G.; Cha, H.-J.; Bills, G. F. Fungal Biology Reviews 2016, 30, 163-175.
(9) Overy, D. P.; Rämä, T.; Oosterhuis, R.; Walker, A. K.; Pang, K. L. Mar. Drugs 2019, 17, 42.

(10) Gessner, M. O.; Van Ryckegem, G., Water Fungi as Decomposers in Freshwater Ecosystems. In Encyclopedia of Environmental Microbiology; John Wiley \& Sons, Inc.: New York, 2003.

(11) Shearer, C. A.; Descals, E.; Kohlmeyer, B.; Kohlmeyer, J.; Marvanová, L.; Padgett, D.; Porter, D.; Raja, H. A.; Schmit, J. P.; Thorton, H. A.; Voglymayr, H. Biodiversity and Conservation 2007, 16, 49-67.

(12) Bärlocher, F. Fungal Ecology 2016, 19, 14-27.

(13) Ingold, C. T. Trans. Br. Mycol. Soc. 1942, 34, 210-215.

(14) Fisher, P. Trans. Br. Mycol. Soc. 1977, 68, 407-411.

(15) Goh, T. K.; Hyde, K. D. J. Ind. Microbiol. 1996, 17, 328-345.

(16) Hibbett, D.; Abarenkov, K.; Kõljalg, U.; Öpik, M.; Chai, B.; Cole, J.; Wang, Q.; Crous, P.; Robert, V.; Helgason, T.; Herr, J. R.; Kirk, P.; Lueschow, S.; O’Donnell, K.; Nilsson, R. H.; Oono, R.; Schoch, C.; Smyth, C.; Walker, D. M.; Porras-Alfaro, A.; Taylor, J. W.; Geiser, D. M. Mycologia 2016, 108, 1049-1068.

(17) Hawksworth, D. L.; Lücking, R. Fungal Kingdom 2017, 79-95.

(18) Blackwell, M. Am. J. Bot. 2011, 98, 426-438.

(19) Wong, M. K. M.; Goh, T. K.; Hodgkiss, I. J.; Hyde, K. D.; Ranghoo, V. M.; Tsui, C. K. M.; Ho, W. H.; Wong, W. S. W.; Yuen, T. K. Biodiversity and Conservation 1998, 7, 1187-1206.

(20) Raja, H. A.; Shearer, C. A.; Tsui, C. K. M. Freshwater Fungi. In eLS. John Wiley \& Sons Ltd: Chichester, 2018; http://www.els.net.

(21) Ingold, C. T. Trans. Br. Mycol. Soc. 1951, 34, 210-215.

(22) Ingold, C. T. Trans. Br. Mycol. Soc. 1954, 37, 1-18.

(23) Ingold, C. T. Trans. Br. Mycol. Soc. 1955, 38, 157-168.

(24) Ingold, C. T.; Chapman, B. Trans. Br. Mycol. Soc. 1952, 35, 268-272.

(25) Webster, J.; Descals, E., Morphology, distribution and ecology of conidial fungi in freshwater habitats. In Biology of Conidial Fungi; Dekker, M., Ed.; Academic Press: New York, 1981; Vol. 1, pp 459681.

(26) Bärlocher, F.; Boddy, L. Fungal Ecology 2016, 19, 5-13.

(27) Bärlocher, F. Research on aquatic hyphomycetes: historical background and overview. In The Ecology of Aquatic Hyphomycetes; Springer, 1992; pp 1-15.

(28) Shearer, C. The Role of Woody Debris. In The Ecology of Aquatic Hyphomycetes. Ecological Studies (Analysis and Synthesis); Bärlocher, F., Ed.; Springer: Berlin, Heidelberg, 1992; Vol. 94, pp 7798

(29) Fisher, P. J.; Webster, J. Trans. Br. Mycol. Soc. 1978, 70, 465468.

(30) Voglmayr, H. Can. J. Bot. 1997, 75, 1772-1777.

(31) Voglmayr, H. Mycol. Res. 1997, 101, 337-340.

(32) Voglmayr, H. Plant Syst. Evol. 1997, 205, 185-193.

(33) Voglmayr, H. Mycol. Res. 1998, 102, 410-414.

(34) Voglmayr, H. Stud. Mycol. 2004, 50, 221-228.

(35) Voglmayr, H. Mycotaxon 2011, 116, 191-202.

(36) Zhang, H.; Hyde, K. D.; Mckenzie, E. H.; Bahkali, A. H.; Zhou, D. Cryptogam.: Mycol. 2012, 33, 333-346.

(37) Abdel-Aziz, F. A.; Abdel-Wahab, M. A. Mycotaxon 2011, 114, $33-42$.

(38) Tsui, C. K.; Baschien, C.; Goh, T.-K. Biology and ecology of freshwater fungi. In Biology of Microfungi; Springer, 2016; pp 285313.

(39) Cai, L.; Hyde, K. D.; Tsui, C. K. M. Genera of Freshwater Fungi; Fungal Diversity Research Series 18; Fungal Diversity Press: Hong Kong, 2006; p 261.

(40) Tsui, C. K. M.; Hyde, K. D. Freshwater Mycology; Fungal Diversity Press: Hong Kong, 2003; p 350.

(41) Shearer, C. A.; Langsam, D. M.; Longcore, J. E. Fungi in Freshwater Habitats. In Measuring and Monitoring Biological Diversity: Standard Methods for Fungi; Mueller, G. M.; Bills, G. F.; Foster, M. S., Eds.; Smithsonian Institution Press: Washington, D.C., 2004; pp 513-531.

(42) Hale, M. D.; Eaton, R. A. Mycologia 1985, 77, 447-463.

(43) Hale, M. D.; Eaton, R. A. Mycologia 1985, 77, 594-605. 
(44) Nielsen, J. C.; Grijseels, S.; Prigent, S.; Ji, B.; Dainat, J.; Nielsen, K. F.; Frisvad, J. C.; Workman, M.; Nielsen, J. Nature Microbiology 2017, 2, 17044.

(45) Lind, A. L.; Wisecaver, J. H.; Lameiras, C.; Wiemann, P.; Palmer, J. M.; Keller, N. P.; Rodrigues, F.; Goldman, G. H.; Rokas, A. PLoS Biol. 2017, 15, No. e2003583.

(46) Daniel, J. F. d. S.; Rodrigues Filho, E. Nat. Prod. Rep. 2007, 24, $1128-1141$.

(47) Yamaguchi, K.; Tsurumi, Y.; Suzuki, R.; Chuaseeharonnachai, C.; Sri-Indrasutdhi, V.; Boonyuen, N.; Okane, I.; Suzuki, K.-i.; Nakagiri, A. Mycologia 2012, 104, 1109-1120.

(48) Raja, H. A.; Schmit, J. P.; Shearer, C. A. Biodiversity and Conservation 2009, 18, 419-455.

(49) Hyde, K. D.; Fryar, S.; Tian, Q.; Bahkali, A. H.; Xu, J. Fungal Ecology 2016, 19, 190-200.

(50) Jones, J. M.; Heath, K. D.; Ferrer, A.; Brown, S. P.; Canam, T.; Dalling, J. W. FEMS Microbiology Ecology 2019, 95, No. fiy223.

(51) Shearer, C. A. Am. J. Bot. 1972, 59, 961-969.

(52) Shearer, C.; Von Bodman, S. Mycologia 1983, 75, 518-530.

(53) Descals, E. Bolleti Soc. d'Història Nat. Balears 1997, 40, 169221.

(54) Shearer, C.; Webster, J. Mycol. Res. 1991, 95, 413-420.

(55) Han, C.; Furukawa, H.; Tomura, T.; Fudou, R.; Kaida, K.;

Choi, B.-K.; Imokawa, G.; Ojika, M. J. Nat. Prod. 2015, 78, 639-644.

(56) Soe, T. W.; Han, C.; Fudou, R.; Kaida, K.; Sawaki, Y.; Tomura,

T.; Ojika, M. J. Nat. Prod. 2019, 82, 1971-1978.

(57) Oh, H.; Kwon, T. O.; Gloer, J. B.; Marvanová, L.; Shearer, C. A. J. Nat. Prod. 1999, 62, 580-583.

(58) VanderMolen, K. M.; Raja, H. A.; El-Elimat, T.; Oberlies, N. H. AMB Express 2013, 3, 71.

(59) El-Elimat, T.; Raja, H. A.; Day, C. S.; Chen, W.-L.; Swanson, S. M.; Oberlies, N. H. J. Nat. Prod. 2014, 77, 2088-2098.

(60) El-Elimat, T.; Raja, H. A.; Day, C. S.; McFeeters, H.; McFeeters, R. L.; Oberlies, N. H. Bioorg. Med. Chem. 2017, 25, 795804.

(61) El-Elimat, T.; Raja, H. A.; Figueroa, M.; Falkinham, J. O.; Oberlies, N. H. Phytochemistry 2014, 104, 114-120.

(62) Paguigan, N. D.; Raja, H. A.; Day, C. S.; Oberlies, N. H. Phytochemistry 2016, 126, 59-65.

(63) Paguigan, N. D.; Rivera-Chávez, J.; Stempin, J. J.; Augustinović, M.; Noras, A. I.; Raja, H. A.; Todd, D. A.; Triplett, K. D.; Day, C.; Figueroa, M.; Hall, P. R.; Cech, N. B.; Oberlies, N. H. J. Nat. Prod. 2019, 82, 550-558.

(64) Rivera-Chávez, J.; El-Elimat, T.; Gallagher, J. M.; Graf, T. N.; Fournier, J.; Panigrahi, G. K.; Deep, G.; Bunch, R. L.; Raja, H. A.; Oberlies, N. H. Planta Med. 2019, 85, 62-71.

(65) Crane, J.; Shearer, C.; Huhndorf, S. M. Mycologia 1992, 84, 235-240.

(66) Shearer, C.; Hyde, K. Mycologia 1997, 89, 114-119.

(67) Ingold, C. T. Guide to Aquatic Hyphomycetes; Freshwater Biological Association, 1975.

(68) Luo, Z.-L.; Hyde, K. D.; Liu, J.-K. J.; Maharachchikumbura, S. S.; Jeewon, R.; Bao, D.-F.; Bhat, D. J.; Lin, C.-G.; Li, W.-L.; Yang, J. Fungal Diversity 2019, 99, 451-660.

(69) Hirayama, K.; Tanaka, K.; Raja, H. A.; Miller, A. N.; Shearer, C. A. Mycologia 2010, 102, 729-746.

(70) Raja, H. A.; Miller, A. N.; Pearce, C. J.; Oberlies, N. H. J. Nat. Prod. 2017, 80, 756-770.

(71) Shenoy, B. D.; Jeewon, R.; Hyde, K. D. Fungal Diversity 2007, 26 I, $1-54$.

(72) Bruns, T. D.; White, T. J.; Taylor, J. W. Annu. Rev. Ecol. Syst. 1991, 22, 525-564.

(73) Shearer, C. A.; Raja, H. A.; Miller, A. N.; Nelson, P.; Tanaka, K.; Hirayama, K.; Marvanová, L.; Hyde, K. D.; Zhang, Y. Stud. Mycol. 2009, 64, 145-153.

(74) Shearer, C. A.; Pang, K.-L.; Suetrong, S.; Raja, H. A., Phylogeny of Dothideomycetes and other classes of Freshwater Fissitunicate Ascomycota. In Freshwater Fungi and Fungus-Like Organisms; Jones, E.
B. G.; Hyde, K. D.; Pang, K.-L., Eds.; De Gruyter: Boston, 2014; p 496.

(75) Raja, H. A.; Paguigan, N. D.; Fournier, J.; Oberlies, N. H. Mycological Progress 2017, 16, 535-552.

(76) Inderbitzin, P.; Landvik, S.; Abdel-Wahab, M. A.; Berbee, M. L. Am. J. Bot. 2001, 88, 52-61.

(77) Seena, S.; Pascoal, C.; Marvanova, L.; Càssio, F. Fungal Diversity 2010, 44, 77-87.

(78) Bärlocher, F. Fungal Biology Reviews 2007, 21, 19-24.

(79) Belliveau, M. J.-R.; Bärlocher, F. Mycol. Res. 2005, 109, 14071417.

(80) Seena, S.; Marvanová, L.; Letourneau, A.; Bärlocher, F. Fungal Biol. 2018, 122, 965-976.

(81) Seena, S.; Pascoal, C.; Cássio, F.; Duarte, S. PLoS One 2012, 7, e35884.

(82) Voglmayr, H.; Yule, C. M. Mycol. Res. 2006, 110, 1242-1252.

(83) Raja, H.; Schoch, C. L.; Hustad, V.; Shearer, C.; Miller, A. MycoKeys 2011, 1, 63-94.

(84) Tanaka, K.; Hirayama, K.; Yonezawa, H.; Sato, G.; Toriyabe, A.; Kudo, H.; Hashimoto, A.; Matsumura, M.; Harada, Y.; Kurihara, Y. Stud. Mycol. 2015, 82, 75-136.

(85) Réblová, M.; Fournier, J.; štěpánek, V. Mycological Progress 2016, 15, 21.

(86) Réblová, M.; Hernández-Restrepo, M.; Fournier, J.; Nekvindová, J. Stud. Mycol. 2020, 95, 415.

(87) Raja, H. A.; El-Elimat, T.; Oberlies, N. H.; Shearer, C. A.; Miller, A. N.; Tanaka, K.; Hashimoto, A.; Fournier, J. Mycologia 2015, 107, 845-862.

(88) Yamaguchi, K.; Chuaseeharonnachai, C.; Huhtinen, S.; Tsurumi, Y.; Sri-Indrasutdhi, V.; Boonyuen, N.; Okane, I.; Hosoya, T.; Nakagiri, A. Mycoscience 2020, 61, 265.

(89) Shearer, C. A.; Zaremaivan, H. Mycologia 1988, 80, 31-37.

(90) Zare-Maivan, H.; Shearer, C. Mycologia 1988, 80, 365-375.

(91) Zare-Maivan, H.; Shearer, C. A. Int. Biodeterior. 1988, 24, 459474.

(92) Krauss, G. J.; Solé, M.; Krauss, G.; Schlosser, D.; Wesenberg, D.; Bärlocher, F. FEMS Microbiology Reviews 2011, 35, 620-651.

(93) Baldy, V.; Gessner, M. O.; Chauvet, E. Oikos 1995, 74, 93-102.

(94) Gessner, M. O.; Chauvet, E.; Dobson, M. Oikos 1999, 85, 377384.

(95) Simonis, J. L.; Raja, H. A.; Shearer, C. A. Fungal Diversity 2008, $31,135-146$.

(96) Savory, J. Ann. Appl. Biol. 1954, 41, 336-347.

(97) Bärlocher, F.; Kendrick, B. J. Ecol. 1974, 62, 761-791.

(98) Gulis, V.; Kuehn, K. A.; Suberkropp, K., Fungi. In Encylopedia of Inland Waters; Likens, G., Ed.; Elsevier: Oxford, UK, 2009; Vol. 3, pp 233-234.

(99) Nikolcheva, L. G.; Bärlocher, F. Mycological Progress 2004, 3, 41-49.

(100) Park, D. Trans. Br. Mycol. Soc. 1972, 58, 291-299.

(101) Dong, W.; Wang, B.; Hyde, K. D.; McKenzie, E. H. C.; Raja, H. A.; Tanaka, K.; Abdel-Wahab, M. A.; Abdel-Aziz, F. A.; Doilom, M.; Phookamsak, R.; Hongsanan, S.; Wanasinghe, D. N.; Yu, X.-D.; Wang, G.-N.; Yang, H.; Yang, J.; Thambugala, K. M.; Tian, Q.; Luo, Z.-L.; Yang, J.-B.; Miller, A. N.; Fournier, J.; Boonmee, S.; Hu, D.-M.; Nalumpang, S.; Zhang, H. Fungal Diversity 2020, 105, 319-575.

(102) Cai, L.; Hu, D.-M.; Liu, F.; Hyde, K. D.; Gareth-Jones, E. The molecular phylogeny of freshwater Sordariomycetes and discomycetes. In Freshwater Fungi and Fungal-Like Organisms; Jones, E. B. G.; Hyde, K. D.; Pang, K.-L., Eds.; De Gruyter: Berlin, 2014; pp 47-72.

(103) Hyde, K. D.; Jones, E. B. G.; Liu, J.-K.; Ariyawansa, H.; Boehm, E.; Boonmee, S.; Braun, U.; Chomnunti, P.; Crous, P. W.; Dai, D.-Q.; Diederich, P.; Dissanayake, A.; Doilom, M.; Doveri, F.; Hongsanan, S.; Jayawardena, R.; Lawrey, J. D.; Li, Y.-M.; Liu, Y.-X.; Lücking, R.; Monkai, J.; Muggia, L.; Nelsen, M. P.; Pang, K.-L.; Phookamsak, R.; Senanayake, I. C.; Shearer, C. A.; Suetrong, S.; Tanaka, K.; Thambugala, K. M.; Wijayawardene, N. N.; Wikee, S.; Wu, H.-X.; Zhang, Y.; Aguirre-Hudson, B.; Alias, S. A.; Aptroot, A.; Bahkali, A. H.; Bezerra, J. L.; Bhat, D. J.; Camporesi, E.; Chukeatirote, 
E.; Gueidan, C.; Hawksworth, D. L.; Hirayama, K.; De Hoog, S.; Kang, J.-C.; Knudsen, K.; Li, W.-J.; Li, X.-H.; Liu, Z.-Y.; Mapook, A.; McKenzie, E. H. C.; Miller, A. N.; Mortimer, P. E.; Phillips, A. J. L.; Raja, H. A.; Scheuer, C.; Schumm, F.; Taylor, J. E.; Tian, Q.; Tibpromma, S.; Wanasinghe, D. N.; Wang, Y.; Xu, J.-C.; Yacharoen, S.; Yan, J.-Y.; Zhang, M. Fungal Diversity 2013, 63, 1-313.

(104) Bao, D.-F.; McKenzie, E. H. C.; Bhat, D. J.; Hyde, K. D.; Luo, Z.-L.; Shen, H.-W.; Su, H.-Y. Front. Microbiol. 2020, 11, 1606.

(105) Luo, Z.-L.; Hyde, K. D.; Liu, J.-K.; Maharachchikumbura, S. S. N.; Jeewon, R.; Bao, D.-F.; Bhat, D. J.; Lin, C.-G.; Li, W.-L.; Yang, J.; Liu, N.-G.; Lu, Y.-Z.; Jayawardena, R. S.; Li, J.-F.; Su, H.-Y. Fungal Diversity 2019, 99, 451-660.

(106) Li, Y.; Steenwyk, J. L.; Chang, Y.; Wang, Y.; James, T. Y.; Stajich, J. E.; Spatafora, J. W.; Groenewald, M.; Dunn, C. W.; Hittinger, C. T.; Shen, X.-X.; Rokas, A. bioRxiv 2020, in press, 2020.08.23.262857.

(107) Anderson, J. L.; Marvanová, L. bioRxiv 2020, 33, 104.

(108) Peter, M.; Kohler, A.; Ohm, R. A.; Kuo, A.; Krützmann, J.; Morin, E.; Arend, M.; Barry, K. W.; Binder, M.; Choi, C.; Clum, A.; Copeland, A.; Grisel, N.; Haridas, S.; Kipfer, T.; LaButti, K.; Lindquist, E.; Lipzen, A.; Maire, R.; Meier, B.; Mihaltcheva, S.; Molinier, V.; Murat, C.; Pöggeler, S.; Quandt, C. A.; Sperisen, C.; Tritt, A.; Tisserant, E.; Crous, P. W.; Henrissat, B.; Nehls, U.; Egli, S.; Spatafora, J. W.; Grigoriev, I. V.; Martin, F. M. Nat. Commun. 2016, 7, 12662.

(109) Rokas, A.; Wisecaver, J. H.; Lind, A. L. Nat. Rev. Microbiol. 2018, 16, 731-744.

(110) Chiang, Y. M.; Lee, K. H.; Sanchez, J. F.; Keller, N. P.; Wang, C. C. Nat. Prod. Commun. 2009, 4, 1505-1510.

(111) Sudhakar, T.; Dash, S.; Rao, R.; Srinivasan, R.; Zacharia, S.; Atmanand, M.; Subramaniam, B.; Nayak, S. Curr. Sci. 2013, 104, 178.

(112) Osbourn, A. Trends Genet. 2010, 26, 449-457.

(113) Hibbett, D. S.; Stajich, J. E.; Spatafora, J. W. Mycologia 2013, 105, 1339-1349.

(114) Steenwyk, J. L.; Mead, M. E.; Knowles, S. L.; Raja, H. A.; Roberts, C. D.; Bader, O.; Houbraken, J.; Goldman, G. H.; Oberlies, N. H.; Rokas, A. Genetics 2020, 216, 481.

(115) Mead, M. E.; Knowles, S. L.; Raja, H. A.; Beattie, S. R.; Kowalski, C. H.; Steenwyk, J. L.; Silva, L. P.; Chiaratto, J.; Ries, L. N. A.; Goldman, G. H.; Cramer, R. A.; Oberlies, N. H.; Rokas, A. mSphere 2019, 4, No. e00018-19.

(116) Wibberg, D.; Stadler, M.; Lambert, C.; Bunk, B.; Spröer, C.; Rückert, C.; Kalinowski, J.; Cox, R. J.; Kuhnert, E. Fungal Diversity 2020, DOI: $10.1007 / \mathrm{s} 13225-020-00447-5$.

(117) Gloer, J. Applications of Fungal Ecology in the Search for New Bioactive Natural Products. In Environmental and Microbial Relationships. The Mycota, 1st ed.; Wicklow, D.; Soderstrom, B., Eds.; Springer: Berlin, 1997; Vol. IV, pp 249-268.

(118) Gloer, J. B. Applications of Fungal Ecology in the Search for New Bioactive Natural Products. In Environmental and Microbial Relationships. The Mycota; Kubicek, C.; Druzhinina, I., Eds.; Springer: Berlin, Heidelberg, 2007; Vol. 4.

(119) Hernández-Carlos, B.; Gamboa-Angulo, M. M. Phytochem. Rev. 2011, 10, 261-286.

(120) Fakhouri, L.; El-Elimat, T.; Hurst, D. P.; Reggio, P. H.; Pearce, C. J.; Oberlies, N. H.; Croatt, M. P. Bioorg. Med. Chem. 2015, 23, 6993-6999.

(121) Tadpetch, K.; Jeanmard, L.; Rukachaisirikul, V. Tetrahedron Lett. 2017, 58, 3453-3456.

(122) Vema, V. N.; Kumari, Y. B.; Musulla, S.; Addada, R. R.; Alapati, S. R. Tetrahedron Lett. 2018, 59, 4165-4167.

(123) Jeanmard, L.; Iawsipo, P.; Panprasert, J.; Rukachaisirikul, V.; Tadpetch, K. Tetrahedron 2018, 74, 4521-4529.

(124) Gaddam, J.; Reddy, A.; Sarma, A. V. S.; Yadav, J. S.; Mohapatra, D. K. J. Org. Chem. 2020, 85, 12418.

(125) Prabhu, K. S.; Siveen, K. S.; Kuttikrishnan, S.; Jochebeth, A.; Ali, T. A.; Elareer, N. R.; Iskandarani, A.; Quaiyoom Khan, A.; Merhi, M.; Dermime, S.; El-Elimat, T.; Oberlies, N. H.; Alali, F. Q.; Steinhoff, M.; Uddin, S. Biomolecules 2019, 9, 126.
(126) Prabhu, K. S.; Siveen, K. S.; Kuttikrishnan, S.; Iskandarani, A. N.; Khan, A. Q.; Merhi, M.; Omri, H. E.; Dermime, S.; El-Elimat, T.; Oberlies, N. H.; Alali, F. Q.; Uddin, S. Front. Pharmacol. 2018, 9, 720.

(127) Oberlies, N. H.; Knowles, S. L.; Amrine, C. S. M.; Kao, D.; Kertesz, V.; Raja, H. A. Nat. Prod. Rep. 2019, 36, 944-959.

(128) Jenul, C.; Horswill, A. R. Microbiol. Spectrum 2019, 7, DOI: $10.1128 /$ microbiolspec.GPP3-0031-2018.

(129) Carter, G. T. Nat. Prod. Rep. 2011, 28, 1783-1789.

(130) Hosoe, T.; Gloer, J. B.; Wicklow, D. T.; Raja, H. A.; Shearer, C. A. Heterocycles 2010, 81, 2123-2130.

(131) Hosoe, T.; Gloer, J.; Raja, H.; Shearer, C. Mycotoxins 2010, 60, $1-6$.

(132) Campbell, J.; Ferrer, A.; Raja, H. A.; Sivichai, S.; Shearer, C. A. Can. J. Bot. 2007, 85, 873-882.

(133) Sun, R.; Gao, Y.-X.; Shen, K.-Z.; Xu, Y.-B.; Wang, C.-R.; Liu, H.-Y.; Dong, J.-Y. Phytochem. Lett. 2011, 4, 101-105.

(134) Shen, K.-Z.; Gao, S.; Gao, Y.-X.; Wang, A.-R.; Xu, Y.-B.; Sun, R.; Hu, P.-G.; Yang, G.-F.; Li, A.-J.; Zhong, D.; Liu, H.-Y.; Dong, J.-Y. Planta Med. 2012, 78, 1837-1843.

(135) Sumilat, D. A.; Yamazaki, H.; Kanno, S.-i.; Saito, R.; Watanabe, Y.; Namikoshi, M. J. Antibiot. 2017, 70, 331.

(136) Fisher, P. J.; Anson, A. E.; Webster, J.; Adriaenssens, P.; Whitehurst, J. S. Trans. Br. Mycol. Soc. 1988, 90, 499-502.

(137) Yamazaki, H.; Ukai, K.; Namikoshi, M. Tetrahedron Lett. 2016, 57, 732-735.

(138) Rotinsulu, H.; Yamazaki, H.; Miura, T.; Chiba, S.; Wewengkang, D. S.; Sumilat, D. A.; Namikoshi, M. J. Antibiot. 2017, 70, 967-969.

(139) Abdelwahab, M. F.; Fouad, M. A.; Kamel, M. S.; Özkaya, F. C.; Kalscheuer, R.; Müller, W. E. G.; Lin, W.; Liu, Z.; Ebrahim, W.; Daletos, G.; Proksch, P. Fitoterapia 2018, 128, 258-264.

(140) Ebada, S. S.; Ebrahim, W. Chemistry Select 2019, 4, 98149816.

(141) Schlingmann, G.; Roll, D. M. Chirality 2005, 17, S48-S51.

(142) Dewick, P. M. Medicinal Natural Products: A Biosynthetic Approach., 3rd ed.; John Wiley \& Sons: Chichester, UK, 2009; p 539.

(143) Oh, H.; Swenson, D. C.; Gloer, J. B.; Shearer, C. A. J. Nat. Prod. 2003, 66, 73-79.

(144) Li, C.; Nitka, M. V.; Gloer, J. B.; Campbell, J.; Shearer, C. A. J. Nat. Prod. 2003, 66, 1302-1306.

(145) Dong, J. Y.; Wang, L.; Song, H. C.; Wang, L. M.; Shen, K. Z.; Sun, R.; Li, G. H.; Li, L.; Zhang, K. Q. Nat. Prod. Res. 2010, 24, 1004-12.

(146) Schmidt-Dannert, C. Biosynthesis of Terpenoid Natural Products in Fungi. In Biotechnology of Isoprenoids. Advances in Biochemical Engineering/Biotechnology; Schrader, J., Ed.; Springer: Cham, 2014; Vol. 148.

(147) Reátegui, R. F.; Gloer, J. B.; Campbell, J.; Shearer, C. A. J. Nat. Prod. 2005, 68, 701-705.

(148) Raja, H. A.; Ferrer, A.; Shearer, C. A.; Miller, A. N. Mycoscience 2010, 51, 208-214.

(149) Rukachaisirikul, V.; Kaewbumrung, C.; Phongpaichit, S.; Hajiwangoh, Z. Chem. Pharm. Bull. 2005, 53, 238-240.

(150) Dong, J.-Y.; Song, H.-C.; Li, J.-H.; Wang, C.-R.; Sun, R.; Tang, Y.-S.; Shen, K.-Z.; Wang, L.; Wang, L.-M.; Zhou, Y.-P.; Li, L.; Zhang, K.-Q. Chem. Biodiversity 2009, 6, 569-577.

(151) Bills, G. F.; Platas, G.; Peláez, F.; Masurekar, P. Mycol. Res. 1999, 103, 179-192.

(152) Hensens, O. D.; Liesch, J. M.; Zink, D. L.; Smith, J. L.; Wichmann, C. F.; Schwartz, R. E. J. Antibiot. 1992, 45, 1875-1885.

(153) Masurekar, P. S.; Fountoulakis, J. M.; Hallada, T. C.; Sosa, M. S.; Kaplan, L. J. Antibiot. 1992, 45, 1867-1874.

(154) Schmatz, D. M.; Abruzzo, G.; Powles, M. A.; McFadden, D. C.; Balkovec, J. M.; Black, R. M.; Nollstadt, K.; Bartizal, K. J. Antibiot. 1992, 45, 1886-1891.

(155) Schwartz, R. E.; Sesin, D. F.; Joshua, H.; Wilson, K. E.; Kempf, A. J.; Goklen, K. A.; Kuehner, D.; Gailliot, P.; Gleason, C.; White, R.; et al. J. Antibiot. 1992, 45, 1853-1866. 
(156) Bouffard, F. A.; Zambias, R. A.; Dropinski, J. F.; Balkovec, J. M.; Hammond, M. L.; Abruzzo, G. K.; Bartizal, K. F.; Marrinan, J. A.; Kurtz, M. B. J. Med. Chem. 1994, 37, 222-225.

(157) Chang, Y.-W.; Yuan, C.-M.; Zhang, J.; Liu, S.; Cao, P.; Hua, H.-M.; Di, Y.-T.; Hao, X.-J. Tetrahedron Lett. 2016, 57, 4952-4955.

(158) Zhang, C.-C.; Ding, S.-S.; Shi, W.-S.; Cao, F.; Zhu, H.-J.; Wen, M.-L. Nat. Prod. Res. 2017, 31, 99-103.

(159) Kaida, K.; Fudou, R.; Kameyama, T.; Tubaki, K.; Suzuki, Y.; Ojika, M.; Sakagami, Y. J. Antibiot. 2001, 54, 17-21.

(160) Itabashi, T.; Ogasawara, N.; Nozawa, K.; Kawai, K.-i. Chem. Pharm. Bull. 1996, 44, 2213-2217.

(161) Yamamoto, Y.; Nitta, K.; Oohata, Y.; Furukawa, T. Chem. Pharm. Bull. 1972, 20, 931-935.

(162) Fukami, A.; Nakamura, T.; Kim, Y. P.; Shiomi, K.; Hayashi, M.; Nagai, T.; Yamada, H.; Komiyama, K.; Omura, S. J. Antibiot. 2000, 53, 1215-1218.

(163) Suzuki, K.; Nozawa, K.; Udagawa, S.-i.; Nakajima, S.; Kawai, K.-i. Phytochemistry 1991, 30, 2096-2098.

(164) El-Elimat, T.; Raja, H. A.; Ayers, S.; Kurina, S. J.; Burdette, J. E.; Mattes, Z.; Sabatelle, R.; Bacon, J. W.; Colby, A. H.; Grinstaff, M. W.; Pearce, C. J.; Oberlies, N. H. Org. Lett. 2019, 21, 529-534.

(165) Struchkova, M. I.; Dvoryantseva, G. G.; Belova, T. P.; Sklyar, Y. E.; Evstigneeva, R. P. Chem. Heterocycl. Compd. 1973, 9, 13551360.

(166) Sawai, K.; Okuno, T.; Yoshikawa, E. Agric. Biol. Chem. 1985, 49, 2501-2503.

(167) El-Elimat, T.; Figueroa, M.; Ehrmann, B. M.; Cech, N. B.; Pearce, C. J.; Oberlies, N. H. J. Nat. Prod. 2013, 76, 1709-1716.

(168) Mueller, G.; Bills, G.; Foster, M. Biodiversity of Fungi: Inventory and Monitoring Methods 2004, 1-777.

(169) Ulloa, M.; Hanlin, R. T.; Aguilar, S.; American Phytopathological, S.; Acosta, E. A. Illustrated Dictionary of Mycology; APS Press, 2000.

(170) Kirschner, R. Mycological Progress 2019, 18, 305-312. 